\title{
A GIS-Enabled Approach for Assessing Damage Potential of Levee Systems Based on Underlying Geology and River Morphology
}

\author{
Mustafa Saadi and Adda Athanasopoulos-Zekkos \\ Civil and Environmental Engineering, University of Michigan, Ann Arbor, MI 48109, USA \\ Correspondence should be addressed to Adda Athanasopoulos-Zekkos; addazekk@umich.edu
}

Received 17 July 2013; Accepted 13 October 2013

Academic Editor: Anaxagoras Elenas

Copyright (C) 2013 M. Saadi and A. Athanasopoulos-Zekkos. This is an open access article distributed under the Creative Commons Attribution License, which permits unrestricted use, distribution, and reproduction in any medium, provided the original work is properly cited.

\begin{abstract}
Flood protection levee systems are complex, interconnected systems, where failure at one location means failure of the entire system. Levees are formed through various geologic processes and human activities over time and information regarding soil properties is collected only at limited point locations and varies significantly both laterally and with depth. Prediction of levee performance in locations where no soil data is available becomes a limitation for system risk assessment studies. Geographic Information Systems (GIS) are particularly suitable for the complex and efficient management of spatial information, georeferencing capabilities, and geostatistical analysis. A GIS enabled approach for assessing damage potential of levees systems is presented. Spatial variability of soil properties is correlated with regional variables such as distance from nearest river segment, river meandering sinuosity index, and surface geology. A geostatistical ordinary kriging approach is used for developing these correlations. Soil strength parameters of identified levee stratigraphy layers were statistically analyzed using a geostatistical ordinary kriging approach and correlated with preselected regional variables. A levee system in Northern California is used as a pilot study for the proposed approach. Excessive underseepage and loss of freeboard due to soil liquefaction are evaluated as the two damage indices for earthen levees.
\end{abstract}

\section{Introduction}

Flood protection systems are important parts of the civil infrastructure of the United States. Recent natural disasters like Hurricane Katrina have provided warnings with regard to the need to maintain and upgrade the aging and deteriorating flood protection systems. Furthermore, the American Society of Civil Engineers (ASCE), in its most recently released Infrastructure Report Card [1], gave the country's infrastructure an overall average performance grade of D (poor) in a scale from A (exceptional) to $\mathrm{F}$ (failing). The newest infrastructure category, levees, received a D- (i.e, poor: the infrastructure is in poor to fair condition and mostly below standard, with many elements approaching the end of their service life. A large portion of the system exhibits significant deterioration. Condition and capacity are of significant concern with strong risk of failure). The Department of Water Resources (DWR) in California is currently helping in leading the efforts for improving the nation's flood protection infrastructure by reevaluating the vulnerability of the flood protection systems in the San Joaquin and Sacramento River Valleys and in the Sacramento Delta region [2,3].

The vast majority of US river cities, now growing at increasing rates, are protected from flooding by earthen levees. Present day earthen levees are at risk from many causes of failure (Figure 1) including seepage (both underseepage and throughseepage), erosion, and instability due to seismic loading. Seismic loading is a potentially grave hazard in many areas of the nation. Guidelines for a seismic element of levee design have never been implemented as a national standard practice, so there are many thousands of miles of seismically vulnerable levees throughout the nation (Figure 2).

Levee response and performance are dependent on the loading condition, as well as the levee geometry and the properties of the levee materials and the foundation soils. Due to the large physical extent of such systems along rivers 


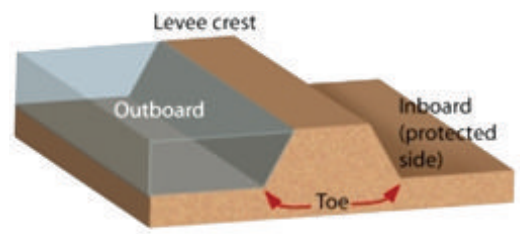

Anatomy of a levee

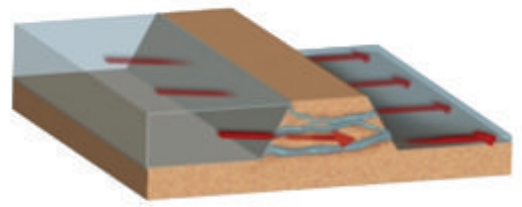

(2) Internal erosion/piping

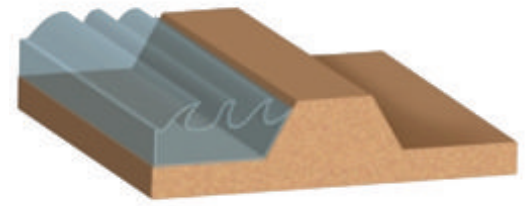

(5) Wave impacts

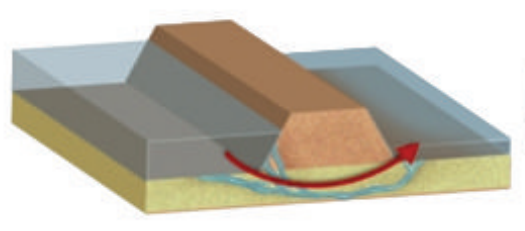

(8) Piping of substratum

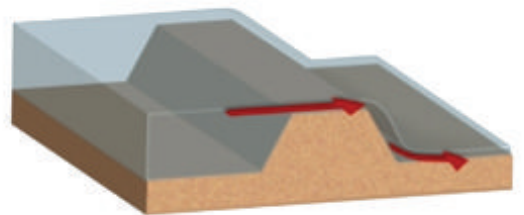

(1a) Overtopping

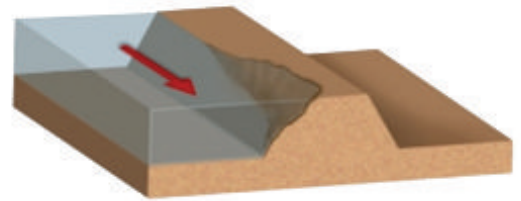

(3) Surface erosion

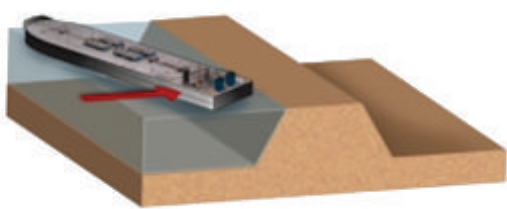

(6) Structural impacts

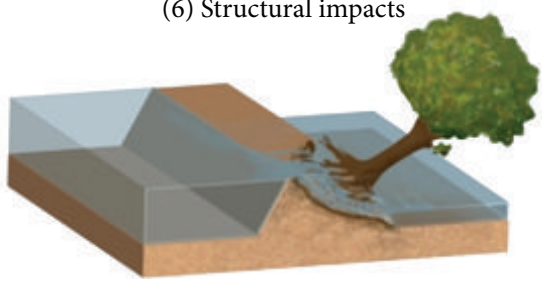

(9) Tree damage

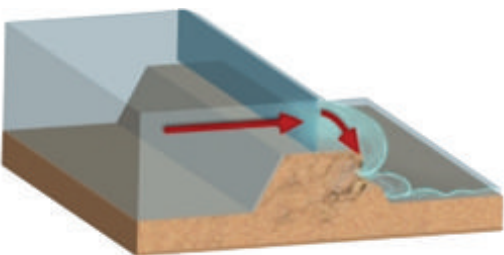

(1b) Overtopping/jetting

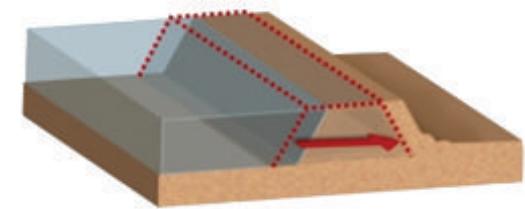

(4) Sliding

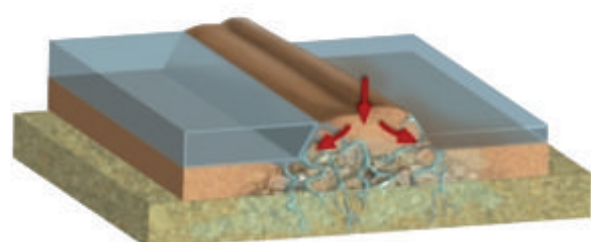

(7) Liquefaction

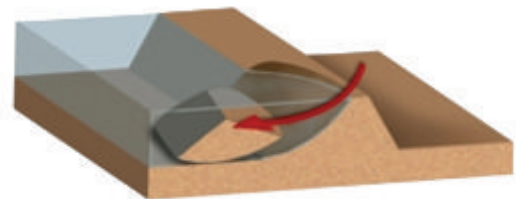

(10) Slope failure

FIGURE 1: Basic levee failure mechanisms [7].

and canals and in the absence of as-built documentation, soil investigation data is at best available at scattered intervals along the levee length, carries a high level of uncertainty, and can be inconsistent, unreliable, or incomplete depending on when and by whom the investigation was carried out.

Earthen flood protection systems are complex, interconnected, adaptive engineered systems where failure at one location means failure of the system, and failure at different locations may result in flooding of different areas. The general risk assessment aspect of such engineered systems has recently become the topic of research efforts such as the Resilient and Sustainable Infrastructure Networks project [10]. However, even though levees stretch for long distances and are in part formed through various geologic processes and human activities over time, information regarding soil properties is collected only at a limited number of point locations and can vary significantly both laterally and with depth. Hence, this becomes a limitation in prediction of the performance of levees in locations where no soil data is available. Analyses with regard to levee vulnerability were performed to date only at locations with known soil properties $[3,11,12]$. A simplified procedure for the assessment of seismic vulnerability at a particular levee location with known soil properties has been proposed $[13,14]$ and is currently being adopted within the Urban Levee Project led by URS Corp. for the Department of Water Resources in California and the under development USACE Guidelines for Seismic Evaluation of Levees, [15]. The spatial continuity of the results, however, is particularly critical in levee systems since failure of a levee at any location could result in the failure of the function of the overall flood protection system. The estimate of the earthen levee response in locations with no available soil data therefore becomes an issue of major concern. As such, it is critically important to develop an approach for assessing the risk of failure continuously along the length of levees. This paper presents an approach for a unified assessment of damage potential of earthen levee systems by developing a GIS-based computational platform that accounts for spatial variability of the soils and includes refined slope stability and liquefaction hazard assessment models, specifically tailored to earthen levees. The main assumptions for the study include a simplified soil characterization of the levee and foundation material, as well as a simplified determination of the probability of failure. Two damage indices were investigated: underseepage and soil liquefaction. Despite these assumptions and simplifications, the pilot study serves as an illustrative example of the application of the proposed methodology. The seismic hazard exposure of the flood protection system in California makes the area specifically appropriate for a pilot study for both 

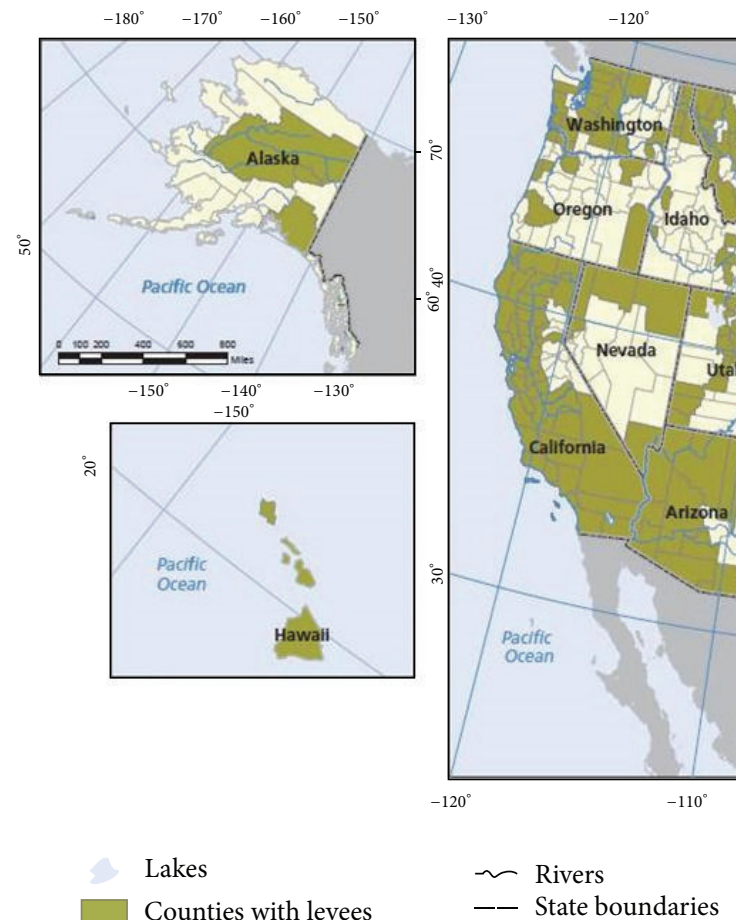

(a)

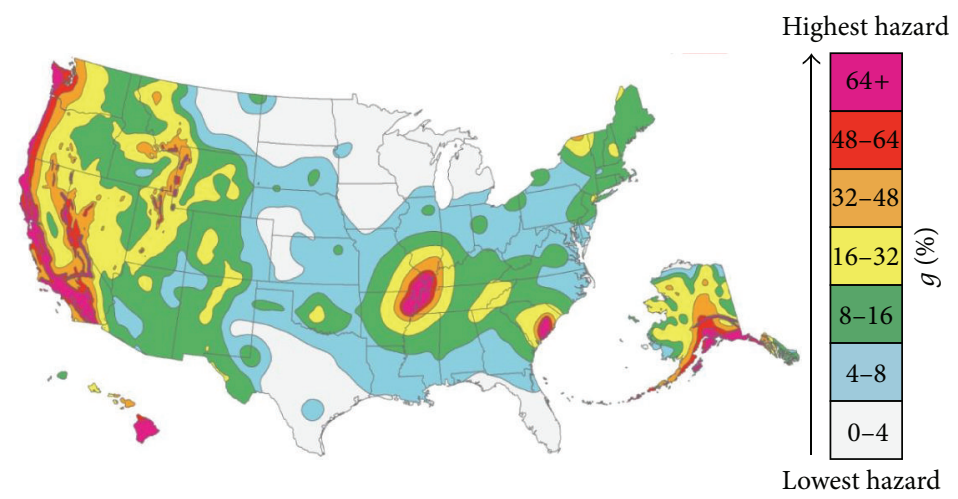

(b)

FIGURE 2: (a) Map of the United States counties that contain levees [8] and (b) National Seismic Hazard Map across the United States showing the levels of horizontal shaking that have a 2 -in-100 chance of being exceeded in a 50 -year period. Shaking is expressed as a percentage of $g$, the acceleration of a falling object due to gravity [9].

modes of failure. A representative region was chosen for the pilot study with a levee system surrounding and protecting a city in Northern California. The area is representative of the region which constitutes the greatest population density in Northern California and carries more than $25 \%$ of the nation's annualized risk [16].

\section{Previous Work on Spatially Distributed Soil Properties}

Soils and rocks in their natural state are among the most variable of all engineering materials. Quantitative measurements of soil properties in the early 1900s differentiated the new discipline of soil mechanics from the engineering of earth works in the previous periods. However, these measurements revealed a great amount of variability in properties, not only from site to site and layer to layer but even within what seemed to be a homogenous material [22]. The variation in these parameters, due to inherent variations in composition and consistency during formation, is thus a three dimensional problem that involves the vertical stratification at any given point, as well as the planar deviations within a specific layer.

Ranges of data variation for soil property parameters have been reported by many researchers, especially starting in the 1960s [23-26]. Despite the work that has been done on this issue, it is not a closed matter, and more needs to be done, particularly on quantifying the level of additional effort required to improve existing characterization of a particular site [27]. 
TABLE 1: Coefficient of variation for common field measurements [4].

\begin{tabular}{|c|c|c|c|c|c|}
\hline Test type & Property & Soil type & Mean & Units & $\operatorname{COV}(\%)$ \\
\hline \multirow{3}{*}{$\mathrm{CPT}$} & $q_{T}$ & Clay & $0.5-2.5$ & $\mathrm{MN} / \mathrm{m}^{2}$ & $<20$ \\
\hline & $q_{c}$ & Clay & $0.5-2$ & $\mathrm{MN} / \mathrm{m}^{2}$ & $20-40$ \\
\hline & $q_{c}$ & Sand & $0.5-30$ & $\mathrm{MN} / \mathrm{m}^{2}$ & $20-60$ \\
\hline VST & $S_{u}$ & Clay & $5-400$ & $\mathrm{kN} / \mathrm{m}^{2}$ & $10-40$ \\
\hline SPT & $N$ & Clay and sand & $10-70$ & blows/ft & $25-50$ \\
\hline \multirow{7}{*}{ DMT } & A reading & Clay & $100-450$ & $\mathrm{kN} / \mathrm{m}^{2}$ & $10-35$ \\
\hline & A reading & Sand & $60-1300$ & $\mathrm{kN} / \mathrm{m}^{2}$ & $20-50$ \\
\hline & $\mathrm{B}$ reading & Clay & $500-880$ & $\mathrm{kN} / \mathrm{m}^{2}$ & $10-35$ \\
\hline & $\mathrm{B}$ reading & Sand & $350-2400$ & $\mathrm{kN} / \mathrm{m}^{2}$ & $20-50$ \\
\hline & $I_{D}$ & Sand & 1-8 & & $20-60$ \\
\hline & $K_{D}$ & Sand & $2-30$ & & $20-60$ \\
\hline & $E_{D}$ & Sand & $10-50$ & $\mathrm{MN} / \mathrm{m}^{2}$ & $15-65$ \\
\hline \multirow{3}{*}{ PMT } & $P_{L}$ & Clay & $400-2800$ & $\mathrm{kN} / \mathrm{m}^{2}$ & $10-35$ \\
\hline & $P_{L}$ & Sand & $1600-3500$ & $\mathrm{kN} / \mathrm{m}^{2}$ & $20-50$ \\
\hline & $E_{\mathrm{PMT}}$ & Sand & 5-15 & $\mathrm{MN} / \mathrm{m}^{2}$ & $15-65$ \\
\hline \multirow{7}{*}{ Lab Index } & $w_{n}$ & Clay and silt & $13-100$ & $\%$ & $8-30$ \\
\hline & $w_{L}$ & Clay and silt & $30-90$ & $\%$ & $6-30$ \\
\hline & $w_{p}$ & Clay and silt & $15-15$ & $\%$ & $6-30$ \\
\hline & PI & Clay and silt & $10-40$ & $\%$ & $-^{\mathrm{a}}$ \\
\hline & LI & Clay and silt & 10 & $\%$ & $-^{\mathrm{a}}$ \\
\hline & $\gamma, \gamma_{D}$ & Clay and silt & $13-20$ & $\mathrm{kN} / \mathrm{m}^{3}$ & $<10$ \\
\hline & $D_{r}$ & Sand & $30-70$ & $\%$ & $10-40 ; 50-70^{\mathrm{b}}$ \\
\hline
\end{tabular}

${ }^{\mathrm{a}} \mathrm{COV}=(3-1.2 \%) /$ mean; ${ }^{\mathrm{b}}$ the first range of variables gives the total variability for the direct method of determination, and the second range of values gives the total variability for the indirect determination using SPT values.

One way to measure the variability of soil properties is similar to the work by Phoon and Kulhawy [4]. The extent, to which soil data might vary, is measured by the coefficients of variation (COV) for a variety of soil properties (Table 1). The COV is defined as the standard deviation divided by the mean. The range of values of the COV is large and is only reflective of conditions at a particular site. As such, there is a need for extending such measures of variability beyond site specific conditions and applying them to more general conditions of geological or geographical environments such as riverine or deltaic regions, as is the case in this study. Furthermore, although some of the general trends of variability in soil and rock can be anticipated, the uncertainty in practice can be larger than expected, with significant implications to geotechnical design and analysis [27].

In the absence of unlimited resources that would permit as many boreholes and tests as needed, geotechnical engineers find themselves most of the time having to deal with limited site investigation data. The traditional approach in dealing with limitation in design has been to use characteristic values of the soil properties combined with a factor of safety. However, for a particular soil layer, soil parameter data sampled at multiple locations on a site would likely plot in a bell-shaped curve. This variability, even in the smallest of sites, suggests that geotechnical engineering systems are amenable to a statistical approach, and most soil properties can be regarded as random variables conforming to the "normal" or "Gaussian" theoretical distribution, thus established statistical methods based on the normal distribution may safely be applied in estimating design parameters [25, 28].

\section{Field Data Collection and Processing}

To achieve the main objective of this study, it was important to investigate and understand the spatial distribution of soil properties and levee characteristics in a selected geographical area. In this research the dependent variables were selected to be the soil type (e.g., sand, clay, and silt) and its associated properties (e.g., shear strength and unit weight). Independent variables (i.e., river sinuosity, surficial geology, and distance from river) were selected, based on theory and engineering judgment, to correlate with the dependent variables and then apply a geostatistical kriging approach to estimate the dependent variable's spatial distribution. The underlying geology and river geomorphology in the study area have played an important role in identifying these variables in this research project. Geomorphology is by definition the study of landforms, such as naturally formed levees, and the history of formation and dynamic processes that shape them.

A pilot study area was selected so that the previously described variables and correlations could be studied and analyzed. The study area used for this research encompasses the levee system protecting Sacramento City as well as the Feather River, both situated at the northeastern limit of 
TABLE 2: Data types and sources.

\begin{tabular}{ll}
\hline Data & Source \\
\hline Surface soil data & Soil Survey Geographic Database (SSURGO) \\
Underlying geology features & United States Geological Survey (USGS) \\
Hydrological features and characteristics & National Hydrography Dataset (NHD) \\
Ground water table & National Water Information System (USGS) \\
Terrain elevation data & National Elevation Dataset (NED) \\
County limit, cities, and road networks & State, county, and city authorities \\
Population & US Census Bureau \\
Land cover & Multi-Resolution Land Characterization (MRLC) \\
Aerial maps & Bing maps, through the ArcGIS online Server \\
& (i) Soil report for Sacramento City, US Army Corps of Engineers, 1987 \\
Levee geometry and soil properties & (ii) Maps and borehole, URS Corporation and the California \\
& Department of Water Resources Urban Levee Evaluation Program, \\
\end{tabular}

the San Joaquin-Sacramento delta region, where the levee material and cross sections can be considered typical of the area. A possible earthquake related levee system failure in Sacramento alone, as per one estimate, might put at risk more than 400,000 people and 170,000 structures and have a potential economic impact of $\$ 7$ to $\$ 15$ billion [29]. The study area is representative of the larger region constituting the greatest population density in Northern California and carrying more than 25\% of the nation's annualized risk [16]. The specific areas used for data analysis and model development in this study were subsections of the larger SRFCP (Figure 3) grouped as follows:

(1) city of Sacramento, comprising of West Sacramento region and American River,

(2) Feather River, comprising of Feather River South and Reclamation District 784, City of Marysville, and Feather River North.

Data used for this study was collected from a number of sources (Table 2). Due to the spatial distribution of the data, the Geographic Information Systems (GIS) platform was used for reporting and analysing the data. Some of the spatial data was available from online databases such as the United States Geological Survey's Natural Map Viewer [30]. Other data was not available in GIS format, especially data related to geotechnical investigation and levee layouts, and had to be manually digitized.

The levee system is defined as the collection of earthen embankments with a corresponding delineated protected area. The levee system is divided for analysis purposes into segments called levee reaches. Levee reaches can be modeled based on the distribution of levee sections of similar embankment and foundation characteristics.

The underlying foundation geology below the river bed of the Sacramento River in California, according to Helley and Harwood [31], is detailed in Table 3. Manual tracing of the area limits was done using scanned hand-drawn USGS maps and GIS georeferencing and editing tools resulting in Figure 4.
A river's sinuosity is its tendency to meander back and forth across the floodplain over time, in what looks like an S-shaped pattern (Figure 5(a)). Mount [32] states that the scarcity of "perfectly straight" rivers in nature is widely believed to indicate that meandering is the more preferred state of single channel rivers. The development of sinuosity in a river takes place due to secondary flow (flow that moves downstream in a cylindrical spiral motion within the channel). The longitudinal bed profile of most rivers is divided into series of alternating high and low gradient segments. This results in the formation of riffles (high points on bed profile) and pools (deep water areas between riffles). In a lowsinuosity low-gradient channel, the overall stream power is usually low, the secondary flow minimal, and thus there is little erosion of the banks and the channel remains relatively static. However, when stream power is great enough, bank erosion will increase initiating the formation of meander bends. Increased meandering and outer bank erosion is matched by increased deposition of material on the opposite bank resulting in alternating point bars along the river length (Figure 5(b)). As a result of the above described process a "relatively straight" river section is expected to have less variability in the properties of the material deposited at its banks than a section that is "meandered."

The meander ratio, or sinuosity index, SI, is a means of quantifying how much a river or stream meanders. It measures the deviation of a river center path length from the shortest possible path and is a reflection of the channel length required to cover a given point-to-point straight line distance. SI is calculated as the length of the river channel center path divided by the straight line length of the valley containing the river. In straight streams, SI $=1.0$, whereas a value of 4.0 is considered to be highly intricate meandering. For this study, and based on classifications by researchers in the field $[5,6]$ the scale shown in Table 4 was adopted.

In order to calculate SI, it is necessary first to define the length of "one meander wave," $L$, similar to the concept of the frequency of a sinusoid wave function (Figure 6). A number of authors $[33,34]$ refer back to the work by Leopold et al. [35] who found that meander wave length $(L)$ varies from 


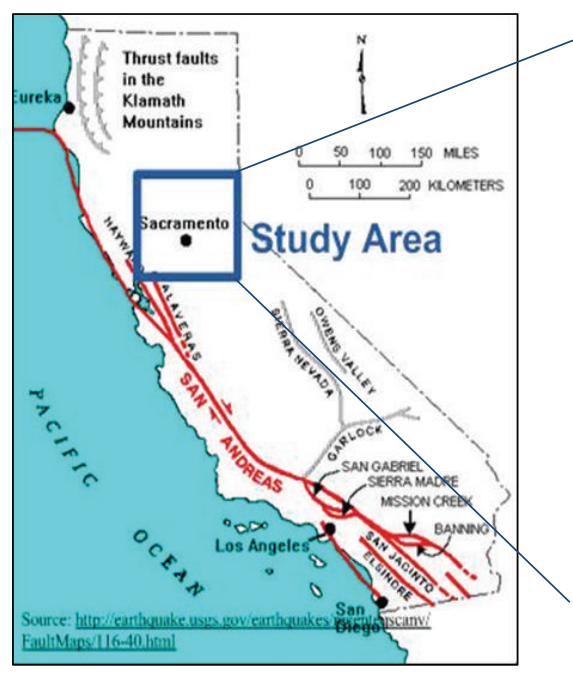

(a)

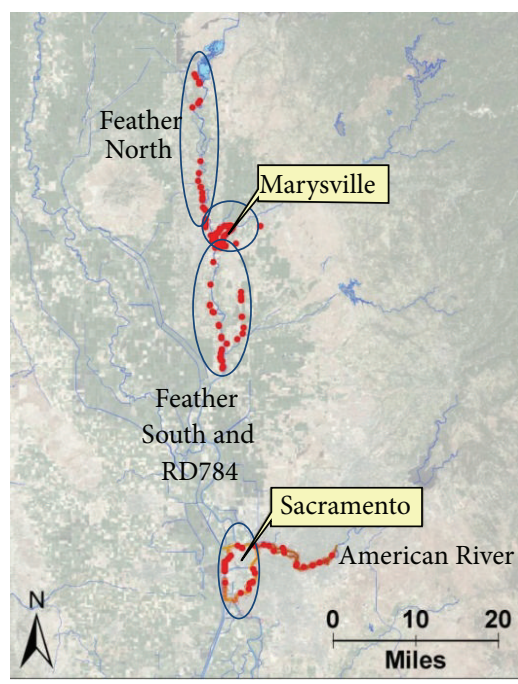

(b)

Figure 3: (a) Location of the study area in the state of California, with (b) close-up view and details of the locations of available geotechnical investigation boreholes around cities of Sacramento and Marysville.

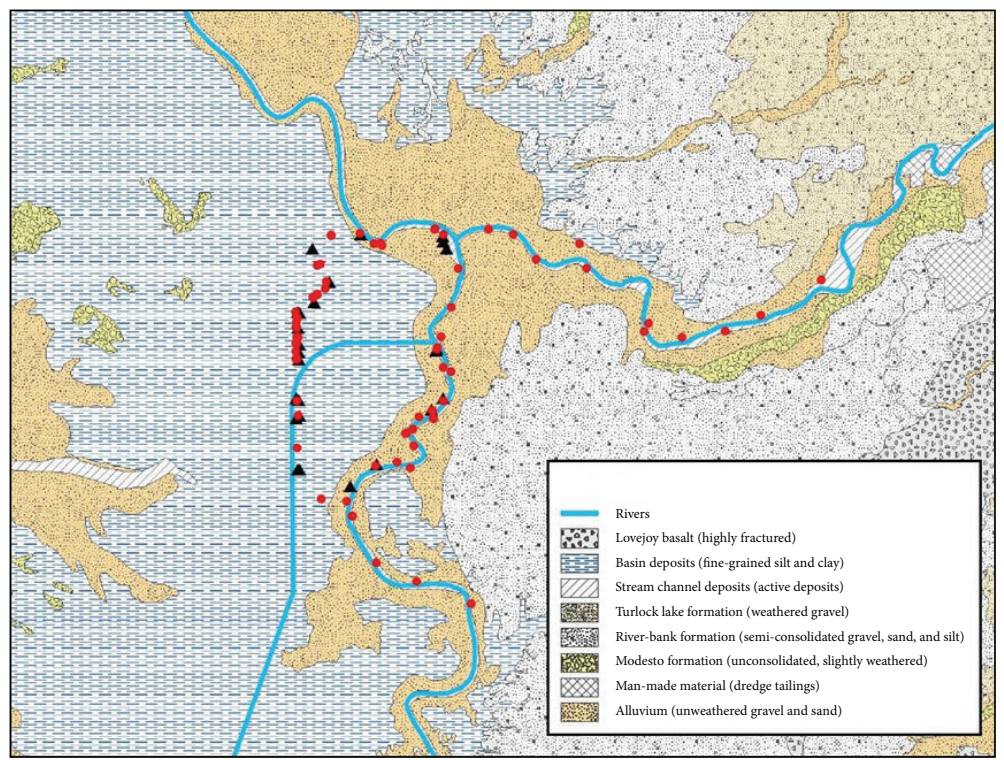

FIGURE 4: Underlying foundation geology regions drawn in ArcGIS reflecting the hand-drawn maps prepared by Helley and Harwood [31].

$L=7.32$ w1.1 to 12.13 w1.09 with the average being roughly equal to 10 times the river channel width " $w$." No streams existing in nature owe all of their sinuosity to hydraulic factors, rather, almost all streams have some degree of both hydraulic and topographic sinuosity [6]. However, for simplicity, it is common to derive the SI based on concepts of hydraulics, which is what has been done in the present study.

A number of meander wave lengths, referred to as river segmentation levels, were applied at the study areas in order to come up with values of SI. The river features are divided into segments, each is equal to the segmentation levee of interest, and the calculated value of the sinuosity index is assigned to the individual segments (Figure 7). For the Sacramento City area, the river width varied from $\sim 70$ to $\sim 210 \mathrm{~m}$, with most river segments widths around the value of $150 \mathrm{~m}$, giving a rough estimate of the expected meander length of $1,500 \mathrm{~m}$. Using the above mentioned equations by Leopold et al. [35] the segmentation levels tried for Sacramento were 500 m, 1500 m, 1750 m, 2500 m, and $3500 \mathrm{~m}$. For Feather River, the width varied from $\sim 60$ to $\sim 150 \mathrm{~m}$, with most river segments widths around the value of $100 \mathrm{~m}$, giving a rough estimate of the expected meander length of $1,000 \mathrm{~m}$. The segmentation levels tried in this area were $500 \mathrm{~m}, 1000 \mathrm{~m}$, $1500 \mathrm{~m}$, and $2500 \mathrm{~m}$.

The issue of sinuosity is further complicated by having single versus multiple parallel river channels. Because of lateral migration of meandering streams, levees should be placed at a fair distance from migrating channels [33]. 


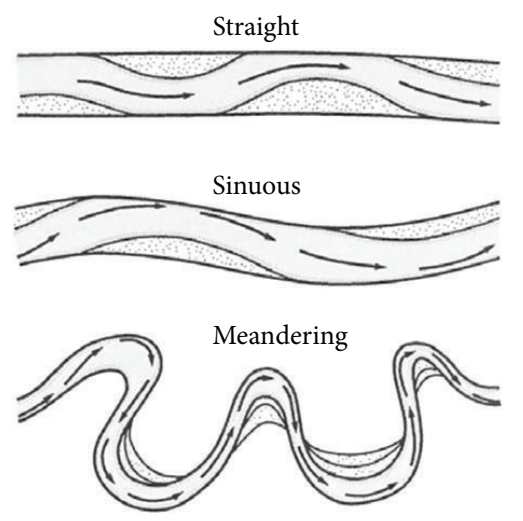

(a)

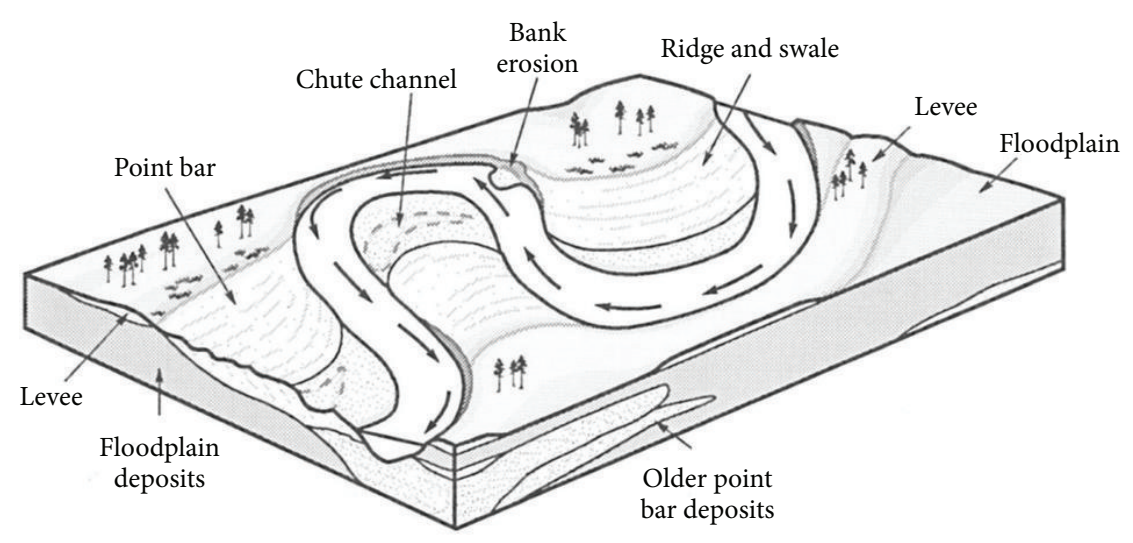

(b)

FIGURE 5: (a) Different levels of river meandering, with arrows indicating location of highest velocity flows and (b) major sedimentary features of a meandering single channel river, showing erosion and deposition process leading to formation of point bars [32].

TABLE 3: Underlying geology classification for the Sacramento River basin.

\begin{tabular}{|c|c|c|c|c|}
\hline Deposit classification & Code & Short description & Geological epoch & Maximum thickness (m) \\
\hline Alluvial deposits & Qa & $\begin{array}{l}\text { Alluvium-unweathered gravel, sand, } \\
\text { and silt }\end{array}$ & Holocene & 10 \\
\hline Basin deposits & $\mathrm{Qb}$ & $\begin{array}{l}\text { Basin deposits, undivided-Fine } \\
\text { grained silt and clay }\end{array}$ & Holocene & 60 \\
\hline Alluvial deposits & Qsc & $\begin{array}{l}\text { Stream channel deposits of open, } \\
\text { active stream channels (morphology } \\
\text { constantly changing) }\end{array}$ & Holocene & 25 \\
\hline Alluvial deposits & Qmu & $\begin{array}{l}\text { Modesto formation-upper } \\
\text { Member-unconsolidated, } \\
\text { unweathered mix of gravel, sand, silt } \\
\text { and clay }\end{array}$ & Pleistocene & 120 \\
\hline Alluvial deposits & Qml & $\begin{array}{l}\text { Modesto formation-lower } \\
\text { Member-unconsolidated, slightly } \\
\text { weathered gravel, sand, silt, and clay }\end{array}$ & Pleistocene & 120 \\
\hline Alluvial deposits & Qru & $\begin{array}{l}\text { Riverbank formation-upper } \\
\text { Member-unconsolidated alluvium } \\
\text { composed of gravel, sand, and silt }\end{array}$ & Pleistocene & 120 \\
\hline Alluvial deposits & Qrl & $\begin{array}{l}\text { Riverbank formation-lower } \\
\text { Member — semiconsolidated gravel, } \\
\text { sand, and silt }\end{array}$ & Pleistocene & 120 \\
\hline Alluvial deposits & Qsc & $\begin{array}{l}\text { Stream channel deposits of open, } \\
\text { active stream channels (morphology } \\
\text { constantly changing) }\end{array}$ & Holocene & 250 \\
\hline
\end{tabular}

TABLE 4: Level of river meandering as a function of the sinuosity index, SI (after $[5,6])$.

\begin{tabular}{lc}
\hline Sinuosity index, SI & Level of meandering \\
\hline $1.0-1.1$ & Straight \\
$1.1-1.3$ & Sinuous \\
$1.3-1.5$ & Slightly meandering \\
$>1.5$ & Meandering \\
\hline
\end{tabular}

However, this is not always the case, especially in urban areas where insufficient space forces the building of levees at the edge of the stream. In the present study no multiple parallel river channels were included. Thus it becomes important to determine the levee parts located in the highly meandered river sections in order to give them special attention in the analyses. Sacramento River is a meandering singlechannel river that occupies one relatively stable main channel surrounded by an extensive floodplain. It is a prime example of meandering river, although channeling by public works projects has greatly altered the original pattern of such rivers [32].

The ground water table level in the study areas was determined because of its direct effect on the calculation of effective stress values in soil. The results of all calculated groundwater level, from data covering the period from 1983 
TABLE 5: Calculated ground water table (GWT) levels (m) in the study area, mean sea level $=0 \mathrm{~m}$.

\begin{tabular}{lccccc}
\hline \multirow{2}{*}{ Area } & \multicolumn{2}{c}{ Elevation $(\mathrm{m})$ from MSL } & \multicolumn{3}{c}{ Relative depth (m) } \\
& Crest & Toe & GWT & GWT below crest & GWT below toe \\
\hline Feather River North & 30 & 25 & 15 & 15 & 10 \\
Marysville & 27 & 21 & 12 & 15 & 9 \\
Feather River South and RD784 & 22 & 15 & 9 & 13 & 6 \\
Sacramento City & 12 & 6 & 0 & 12 & 6 \\
\hline
\end{tabular}

TABLE 6: Summary of available geotechnical investigation borehole logs and cone penetration tests (CPTs) in the study areas.

\begin{tabular}{|c|c|c|c|c|c|c|c|c|}
\hline \multirow{2}{*}{ Area } & \multicolumn{5}{|c|}{ URS boreholes } & \multirow{2}{*}{$\begin{array}{c}\text { URS } \\
\text { Historical } \\
\text { Historical log }\end{array}$} & \multirow{2}{*}{$\begin{array}{c}\text { USACE } \\
\text { Borehole }\end{array}$} & \multirow{2}{*}{$\begin{array}{c}\text { URS CPTs } \\
\text { CPT }\end{array}$} \\
\hline & Borehole (B) & $\begin{array}{c}\text { Hollow stem } \\
\text { auger (A) }\end{array}$ & $\begin{array}{c}\text { Hand auger } \\
(\mathrm{H})\end{array}$ & Sonic core (S) & $\begin{array}{c}\text { Piezometer } \\
(\mathrm{M})\end{array}$ & & & \\
\hline West Sacramento & 26 & - & - & - & 4 & $9^{a}$ & 34 & 25 \\
\hline American River & 10 & - & - & - & 6 & $27^{\mathrm{a}}$ & - & - \\
\hline Marysville & 49 & - & - & 4 & 16 & - & - & - \\
\hline RD784 & 21 & - & - & 2 & - & - & - & - \\
\hline Feather North & 10 & 14 & 5 & - & - & - & - & 19 \\
\hline Feather South & 14 & $10^{\mathrm{b}}$ & 6 & - & - & - & - & 74 \\
\hline Total & 267 & & & & & & & 118 \\
\hline
\end{tabular}

${ }^{a}$ Many more available. These are a short list of historical boreholes used for this study.

b One borehole was "solid" and not "hollow" stem auger.

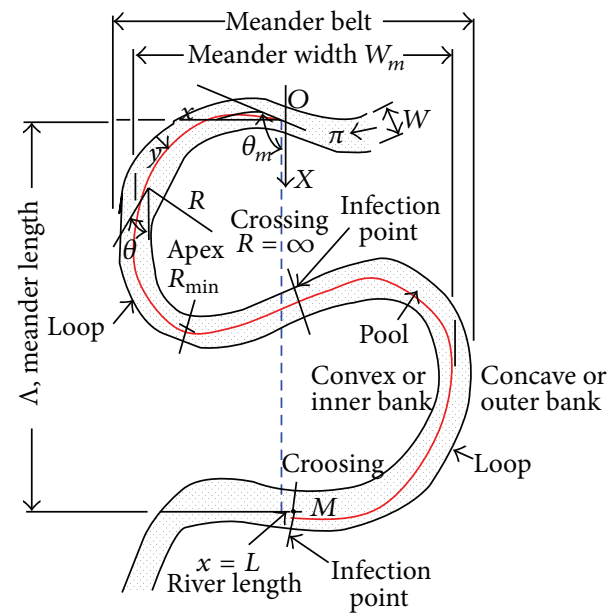

FIGURE 6: Characterization of a meandering river [33]. The sinuosity index is derived by dividing the river length (solid line), $L$, by the straight line valley length (dashed line).

to 2010 [36], are summarized in Table 5 and are in agreement with measurements available from the USACE report [17].

\section{Geotechnical Investigation Data}

As previously mentioned, geotechnical soil investigation data for the study area was collected from (1) URS corporation data from the California Urban Levee Evaluation Project [37] and (2) the USACE investigation report for Sacramento City [17]. Data from both sources included levee layout, levee geometry, boreholes logs, and field tests. The total number of available logs, CPTs, and reported tests are summarized in Tables 6 and 7. All boreholes were digitized into a GIS format, and available test information was extracted for further analysis. Note that a large number of historical boreholes were reported in the URS dataset. No test results were available for these, and they were short-listed and only used in the process of identifying regional stratigraphy.

Laboratory test data reported in the URS database included Consolidated Undrained Strength (CU) and Vane Shear (VS) testing. However, the numerical values of these tests were not provided. Other lab test results included Water Content (WC), Liquid Limit (LL), Plasticity Index (PI), and Fines Content (\%). CPT data was validated through close comparison to nearby borehole logs for soil layer delineation and soil classification. Subsequently, resulting common site specific CPT "signatures" (Figure 8) were developed for areas with no boreholes. CPT cone tip resistance was used to determine Undrained Shear Strength $\left(S_{u}\right)$ of cohesive soils. The following empirical correlation [38] was used (1):

$$
S_{u}=\frac{\left(q_{t}-\sigma_{\mathrm{vo}}\right)}{N_{\mathrm{kt}}},
$$

where $q_{t}$ is the corrected cone resistance, $N_{\mathrm{kt}}$ is an empirical cone factor, and $\sigma_{\mathrm{vo}}$ is the total in situ vertical stress.

The empirical parameter $N_{\mathrm{kt}}$ is site specific and can be back-calculated using available triaxial compression test results [17]. It is worth noting that for the same site, the value of $N_{\mathrm{kt}}$ varies depending on the type of laboratory test used to determine $S_{u}$ [38]. Laboratory measured $S_{u}$ values from USACE boreholes in West Sacramento were paired with corresponding nearby clay layers (at similar depth) from 


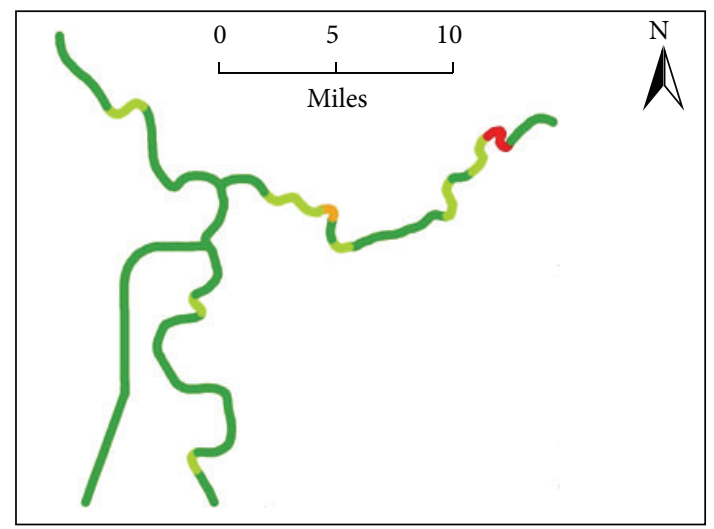

Sinuosity index at $1500 \mathrm{~m}$ segments

- 1-1.1 (straight)

— 1.31-1.5 (slightly meandering)

- 1.11-1.3 (sinuous)

(a)

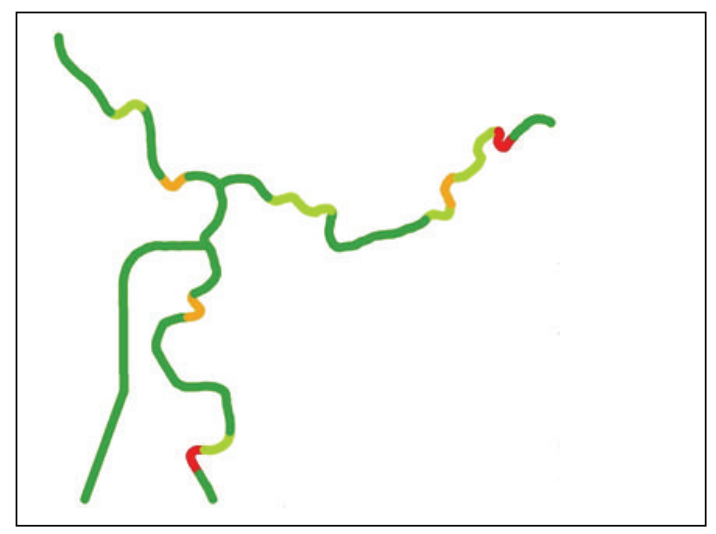

Sinuosity index at $2500 \mathrm{~m}$ segments

- 1-1.1 (straight)

— 1.31-1.5 (slightly meandering)

- 1.11-1.3 (sinuous)

(b)

Figure 7: Comparison of sinuosity index outputs for different river segmentation levels at Sacramento City: (a) segmentation level of 1,500 m and (b) segmentation level of 2,500 m.

the URS CPTs. The back-calculated $N_{\mathrm{kt}}$ values had an average of 20.8 which is within, though at the high end of, ranges of $N_{\mathrm{kt}}$ values reported in the literature [38].

In order to derive friction angle, $\phi$, values for cohesionless soils, Standard Penetration Test (SPT) values $\left(N\right.$ and $\left.N_{60}\right)$ had to be adjusted to $N_{1,60}$ using required correction factors and effective stress calculations made possible by the determined ground water table levels. A number of approaches were used for estimating friction angle, $\phi$, values and are compared in Table 8. The friction angle in this study was derived from SPT using Kulhawy and Mayne [18] and from Cone Penetration Test (CPT) results using Robertson and Campanella [39]. Figure 8 shows a comparison of CPT data from this study with the soil classification chart proposed by Olsen and Mitchell [40].

\section{Prediction of Regional Soil Stratigraphy}

Prior to estimating the spatial variability of soil parameters, there is a need to estimate the soil stratigraphy in the area of study. Due to the increased uncertainties in derivation of strength parameters from in situ tests for silts, the focus was to determine the stratigraphy of sands and clays, since the derivation of strength parameters for those two categories of soils was possible given the available data. Therefore, a general category of "sand" was adopted for soils classified, according to the Unified Soil Classification System (USCS) [41], as poorly-graded sand (SP), well-graded sand (SW), poorly-graded sand with silt, that is, $5 \%<\%$ Fines $<12 \%$ (SP$\mathrm{SM}$ ), and well-graded sand with silt, that is, $5 \%<\%$ Fines $<12 \%$ (SW-SM). Similarly, a general category of "clay" was adopted for soils classified as fat clay $(\mathrm{CH})$, lean clay $(\mathrm{CL})$ and silty clay (CL-ML), according to USCS.

Furthermore, because of the geostatistical complexity of combining both the estimation of thickness variation of different layer types (qualitative parameter), with the estimation

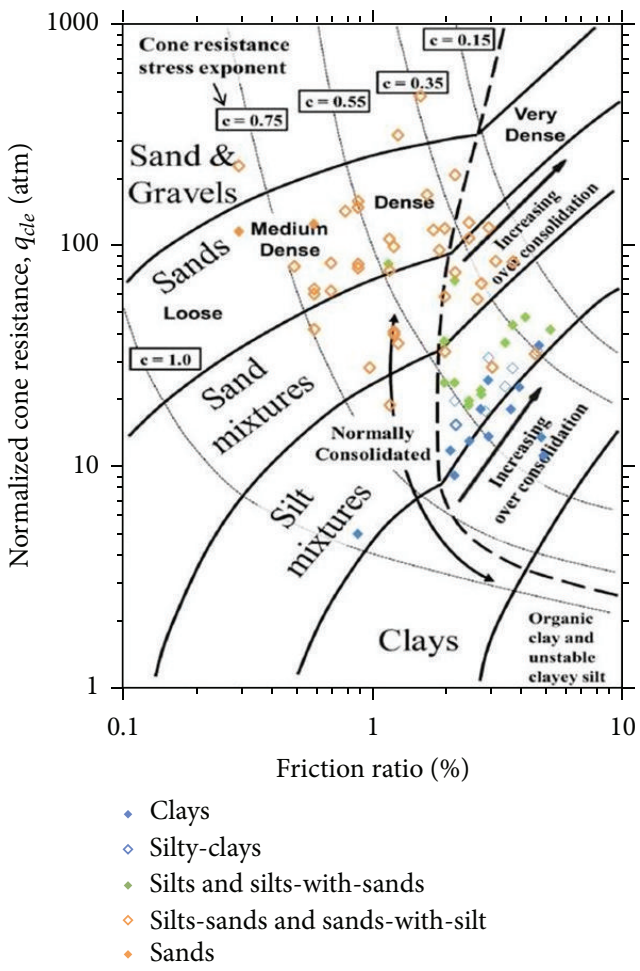

FIGURE 8: Example of collected CPT data from Sacramento City area plotted on the Olsen and Mitchell [40] soil classification chart.

of the soil parameter variability within each layer (quantitative parameter), and because the focus of this research was the study of soil properties variability, soil layers were assumed to exist at a constant thickness throughout the study areas. For each of the two study areas (Sacramento and Feather River) and based on the available borehole log classifications, plots were developed to help identify the stratigraphy of 
the region. These plots do not include material identified as engineering fill within the levee, as the intent of the research is to study the spatial variation of naturally occurring soils. The plots also confirm that, within the area of study, the regional stratigraphy can be assumed to be uniform for the scope of this research. The layer delineation is determined based on the number of data points occurring with depth, in combination with the layer thickness for each data point in the respective borehole log. The "layer range" value for each identified layer represents the thickness of the band of soil where the identified layer was observed. The delineation of clay layers takes into account the corresponding delineation of the sand layers, and vice versa. As an example, Figure 9 shows the approach used for the delineation of layers in the Sacramento area based on available boreholes from USACE and URS datasets. The layers identified in Sacramento from Figure 9 are listed in Table 9. Similarly the resulting layer delineation for Feather River was performed using the URS boreholes, and the results are presented in Table 10. The number of layers observed was dependent on the limitation of depth of boreholes.

The following steps have been applied to all layers of both study areas. However, only figures relating to the identified "shallow clay layer in Sacramento" (the top layer in Figure 9) will be used as examples in the coming sections.

\section{Prediction of Spatial Variability of Soil Parameters}

6.1. Correlation of Soil Parameters with Regional Factors. For the delineated layers of clay and sand, the soil parameters that were studied were as follows: for sands, friction angle $(\phi)$ and fines content (\%) and for clays, undrained shear strength $\left(S_{u}\right)$, liquid limit $(\mathrm{LL})$, plasticity index $(\mathrm{PI})$, and ratio of water content to liquid limit (WC/LL).

The parameters were analyzed and correlations were developed, where applicable, with regional factors including distance to closest river, sinuosity of closest river segment, and underlying geology classification. The concept of "effective correlation distance" between the soil parameters and the factors was introduced, representing the distance beyond which no trend/correlation was observed or deemed physically significant. The "effective correlation distance" was determined from data in this study and could possibly change if additional data are provided in the future. Figure 10 is shown, as an example, for the shear strength parameter $S_{u}$ of the Sacramento area shallow clay layer. As seen in the figure the $S_{u}$ values increase with distance from the river up until $600 \mathrm{~m}$ but no specific trend is apparent for distances larger than $600 \mathrm{~m}$. A possible explanation for this trend is that shallow clays close to the river have been deposited either more recently or have exhibited higher water tables and are therefore normally consolidated as opposed to shallow clays further away from the river where the water table may be lower allowing for overconsolidation of the clays and increase of $S_{u}$. Tables 11 and 12 show the established "effective correlation distance" and the "sinuosity index segmentation level" for all seven layers. The latter is a reflection of the river meander length period.

Figure 11 summarizes the plots of the shallow clay layer parameters $\left(S_{u}, \mathrm{LL}, \mathrm{PI}\right.$, and WC/LL) in Sacramento in relation to the distance from the centerline of closest river segment. A further analysis of the particular relation between $S_{u}$ with geology (Figure 12) and sinuosity index (Figure 13) helps to establish preliminary relationships. For example, the latter figure implies that the value of $S_{u}$ decreases with increased river sinuosity. The $X$-axis values in Figure 12, representing geology, are categorical values, thus no trend or fit can be deduced, but rather variability of $S_{u}$ parameter with each particular geology type is established (Table 3 ).

6.2. Observations of Local versus Regional Effects. Clay in both shallow and deep layer and in both areas of study showed increasing trend of $S_{u}$ with increasing distance from river (Figure 14). $S_{u}$ values also increased with depth, which may be attributed to consolidation of the deeper layers over time.

As for relation of $S_{u}$ to the different geological formations in the two study areas (Figure 15), a general observation is that clay $S_{u}$ values in the areas of the Qa formation tend to have lower values than other areas. The Qa formation is defined as Alluvium-unweathered gravel, sand, and silt, as such clay is not the main component, which might provide an explanation for the lower values of $S_{u}$ for clay in these areas, as compared to other formations.

Figure 16 shows the observed $S_{u}$ relation to sinuosity index (SI). The higher number of data points at this low sinuosity level is due to the smaller number of river segments that are highly sinuous. An important observation across all areas of study and at shallow and deep clay layers is that $S_{u}$ tends to decrease with increasing sinuosity of the closest river segment. A possible explanation of this phenomenon is that deposition of fine particles tends to be more uniform (leading to higher $S_{u}$ values) if the river is less sinuous. Given the limited available data, however, it should be noted that more data points are needed to develop more robust correlations between SI and shear strength or soil type. Furthermore, due to the specific case study area that was used, the limited data was primarily available for SI values close to 1 (i.e., straight river sections). Note that the sinuosity is based on segmentation level of 1,750 $\mathrm{m}$ for Sacramento and 1,000 $\mathrm{m}$ for Feather River as discussed in Section 3.

6.3. Kriging Estimation Using Measured Parameter Values. The spatial variation of the soil strength parameters in the vicinity of levees was estimated by the ordinary kriging approach. The choice for ordinary kriging assumes that the local mean $\mathrm{m}(\mathrm{u})$ is not necessarily closely related to the population (overall) mean and so only uses the samples (known values) in the local neighborhood of the estimate. The following steps demonstrate how to revise a spatially based kriging (solely based on distance between known points) into a revised kriged map that reflects correlation of soil parameters with regional factors in the riverine environment of the Sacramento River basin. 
TABLE 7: Reported number of field and lab tests within the available geotechnical investigation boreholes and cone penetration tests (CPTs) in the study areas.

\begin{tabular}{|c|c|c|c|c|c|c|c|c|c|c|c|c|c|}
\hline \multirow{2}{*}{ Area } & \multicolumn{9}{|c|}{ URS boreholes and USACE } & \multicolumn{4}{|c|}{ URS CPTs } \\
\hline & SPT & $M C^{a}$ & $\mathrm{CU}^{\mathrm{b}}$ & $\mathrm{VS}^{\mathrm{b}}$ & WC & LL & PI & Fines & $\mathrm{UU}^{\mathrm{c}}$ & $\mathrm{Rf}^{\mathrm{d}}$ & $\mathrm{qt}^{\mathrm{d}}$ & $\mathrm{fs}^{\mathrm{d}}$ & $\mathrm{u}_{2}{ }^{\mathrm{d}}$ \\
\hline West Sacramento & 648 & 46 & 11 & 2 & 173 & 166 & 166 & 298 & 30 & 25 & & & \\
\hline American River & 133 & 4 & - & - & 35 & 13 & 12 & 56 & - & - & & & \\
\hline Marysville & 651 & 19 & 15 & - & 39 & 35 & 35 & 90 & - & - & & & \\
\hline RD784 & 217 & 25 & 19 & - & 111 & 96 & 96 & 158 & - & - & & & \\
\hline Feather North & 211 & 2 & 7 & - & 27 & 25 & 25 & 81 & - & 19 & & & \\
\hline Feather South & 233 & - & 22 & - & 93 & 84 & 84 & 123 & - & 74 & & & \\
\hline Total & 2093 & & & & 478 & 419 & 418 & 806 & 30 & & & & \\
\hline
\end{tabular}

${ }^{a}$ Modified California test numbers to be converted to SPT equivalent.

${ }^{\mathrm{b}}$ Numerical results for Consolidated Undrained (CU) triaxial tests and Vane Shear (VS) tests were not provided.

${ }^{\mathrm{c}}$ Unconsolidated Undrained (UU) triaxial tests were only available from the USACE [17] data.

${ }^{\mathrm{d}}$ CPT logs represent continuous measurement of parameters.

TABLE 8: Relationship between $N_{1,60}$, density, and friction angle of sands.

\begin{tabular}{lccccc}
\hline \multirow{2}{*}{$N_{1,60}$} & \multirow{2}{*}{ Density } & Kulhawy and Mayne [18] & Peck et al. [19] & Schmertmann [20] & Hatanaka and Uchida [21] \\
\hline$<5$ & Very loose & $<31$ & $<29$ & $<28$ & $<30$ \\
$5-15$ & Loose & $30-36$ & $29-31$ & $28-38$ & $30-37$ \\
$15-30$ & Medium & $35-41$ & $31-35$ & $38-44$ & $37-44$ \\
$30-50$ & Dense & $40-46$ & $35-41$ & $44-49$ & $44-52$ \\
$>50$ & Very dense & $>42$ & $>41$ & $>49$ & $>50$ \\
\hline
\end{tabular}

TABLE 9: Delineation of clay and sand layers in Sacramento area.

\begin{tabular}{|c|c|c|c|c|c|c|c|}
\hline \multirow{2}{*}{ Location } & \multirow{2}{*}{ Material } & \multirow{2}{*}{ Depth } & \multirow{2}{*}{ Depth order } & \multirow{2}{*}{ Layer ref. } & \multicolumn{3}{|c|}{ Absolute elevation $(\mathrm{m}) \mathrm{MSL}=0$} \\
\hline & & & & & From & To & Layer Range \\
\hline \multirow{4}{*}{ Sacramento City } & Clay & Shallow & 1 & 1st clay & 4 & -4 & 8 \\
\hline & Sand & Shallow & 2 & 1st sand & -2 & -10 & 8 \\
\hline & Clay & Deep $^{a}$ & 3 & 2nd clay & -11 & -19 & 8 \\
\hline & Sand & Deep $^{a}$ & 4 & 2nd sand & -18 & -25 & 7 \\
\hline
\end{tabular}

${ }^{\mathrm{a}}$ Data available only from West Sacramento URS dataset.

TABLE 10: Delineation of clay and sand layers in Feather River area.

\begin{tabular}{|c|c|c|c|c|c|c|c|}
\hline \multirow{2}{*}{ Location } & \multirow{2}{*}{ Material } & \multirow{2}{*}{ Depth } & \multirow{2}{*}{ Depth order } & \multirow{2}{*}{ Layer ref. } & \multicolumn{3}{|c|}{ Absolute elevation $(\mathrm{m}) \mathrm{MSL}=0$} \\
\hline & & & & & From & To & Layer range \\
\hline Feather South and RD784 & \multirow{3}{*}{ Clay } & \multirow{3}{*}{ Shallow } & \multirow{3}{*}{1} & \multirow{3}{*}{ 1st clay } & 17 & 10 & 7 \\
\hline Marysville & & & & & 22 & 13 & 9 \\
\hline Feather North & & & & & 25 & 17 & 8 \\
\hline Feather South and RD784 & \multirow{3}{*}{ Sand } & \multirow{3}{*}{ Shallow } & \multirow{3}{*}{2} & \multirow{3}{*}{ 1st sand } & 11 & 6 & 5 \\
\hline Marysville & & & & & 15 & 8 & 7 \\
\hline Feather North & & & & & 20 & 12 & 8 \\
\hline Feather South and RD784 & \multirow{3}{*}{ Clay } & \multirow{3}{*}{ Deep } & \multirow{3}{*}{3} & \multirow{3}{*}{ 2nd clay } & 7 & 0 & 7 \\
\hline Marysville & & & & & 7 & 0 & 7 \\
\hline Feather North & & & & & 12 & 6 & 6 \\
\hline
\end{tabular}




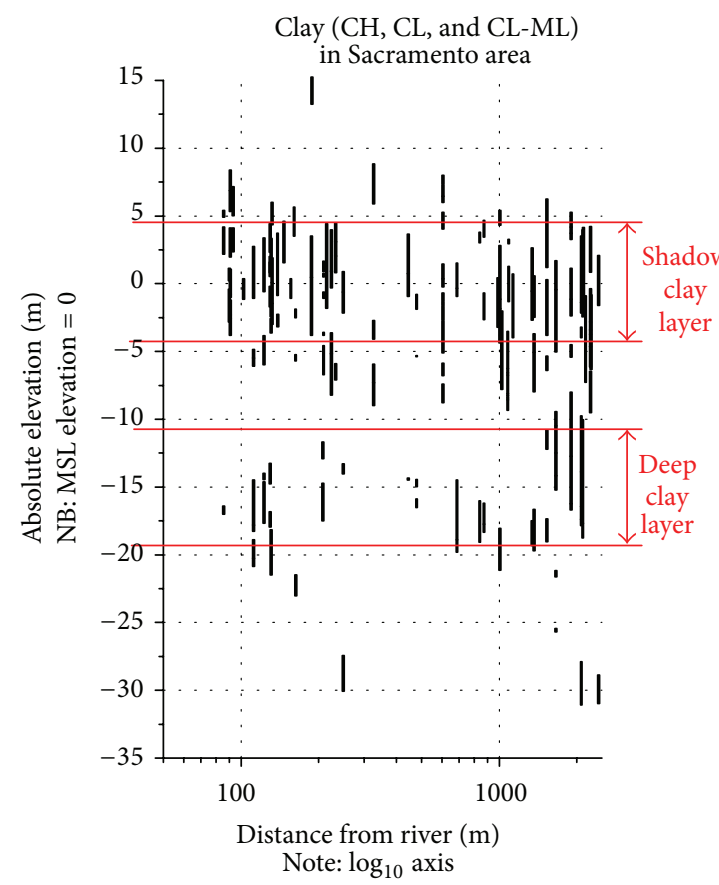

(a)

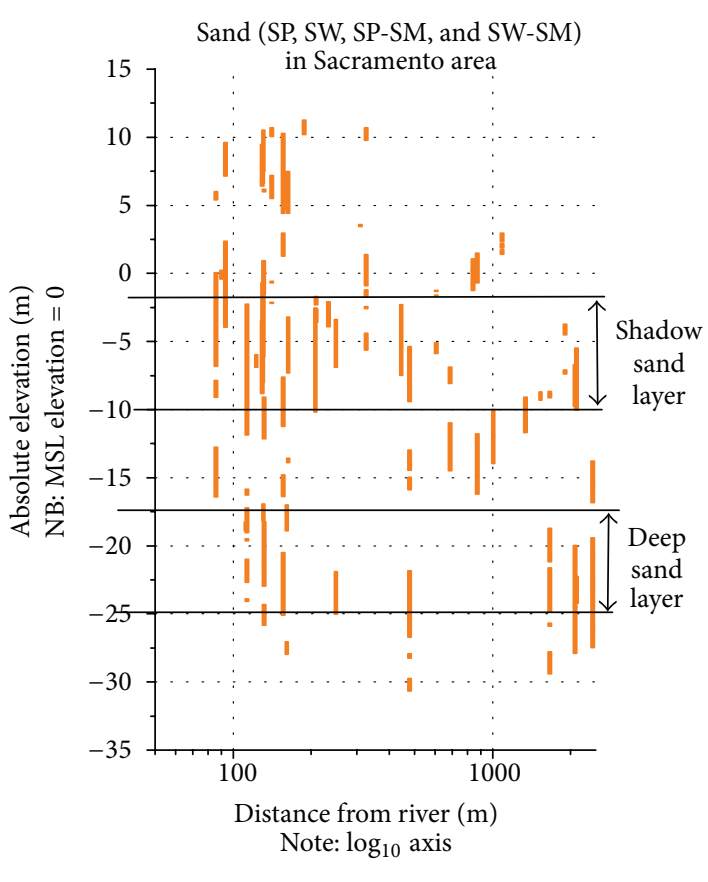

(b)

FIGURE 9: Process of layers delineation for clay and sand in Sacramento based on borehole log information.

TABLE 11: "Effective correlation distance" and "sinuosity index segmentation level" for soil layers in Sacramento area.

\begin{tabular}{|c|c|c|c|c|c|c|c|c|c|}
\hline \multirow{2}{*}{ Location } & \multirow{2}{*}{ Material } & \multirow{2}{*}{ Depth } & \multirow{2}{*}{ SI segmentation level $(\mathrm{m})$} & \multicolumn{6}{|c|}{ Effective correlation distance (m) } \\
\hline & & & & $\phi$ & Fines & $S_{u}$ & LL & PI & WC/LL \\
\hline \multirow{4}{*}{ Sacramento City } & Clay & Shallow & 1750 & - & - & 600 & 600 & 600 & 1500 \\
\hline & Sand & Shallow & 1750 & 450 & 450 & - & - & - & - \\
\hline & Clay & Deep & 1750 & - & - & $\mathrm{n} / \mathrm{a}^{\mathrm{a}}$ & 1500 & 1500 & 1500 \\
\hline & Sand & Deep & 1750 & 450 & 450 & - & - & - & - \\
\hline
\end{tabular}

${ }^{\mathrm{a}}$ Only three data points, and all are at large distance from the river.

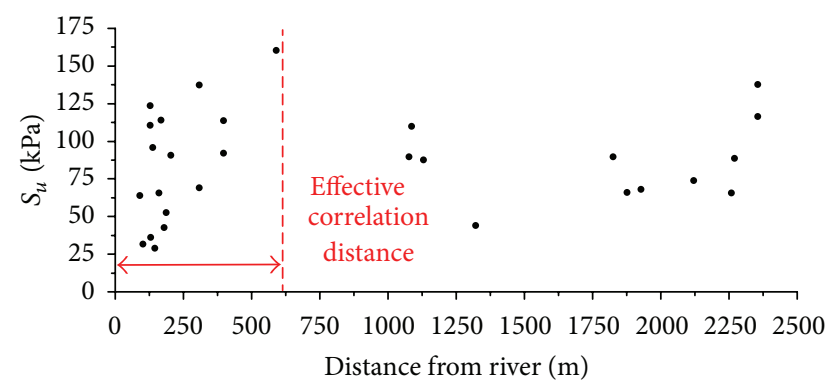

FIGURE 10: Example of determination of the "effective correlation distance" for the shear strength parameter, $S_{u}$, for the Sacramento area shallow clay layer.

Geostatistical analysis was performed using the ArcGIS Geostatistical Analyst software extension. Outputs of the geostatistical analysis of the known sampled data points include the empirical (or experimental) semivariogram, cross validation, and error plots, as well as information pertaining to the main variables of interest at this stage: nugget, range, and sill. A summary of the range, nugget, and partial sill values from the semivariograms is presented in Table 13. The "correlation range" is the distance beyond which no spatial relation exists between points; that is, a known sampled points do not affect measurements at another point situated at this, or a larger, distance. The range value for clay is almost twice as large as the value for most sands. This is consistent with the observation that the effective correlation distance for clays was also larger than that of sand by a similar margin.

Kriging estimate maps were derived, with corresponding semivariograms, for all identified layers in the study areas. A sample map output of the kriging approach for the estimation of the shear strength $S_{u}$ of the shallow foundation clay layer in Sacramento is shown in Figure 17, with shaded colour symbology representing variation of the estimated $S_{u}$ values, classified as soft to medium clay $\left(S_{u}<50 \mathrm{kPa}\right)$, stiff clay $\left(50 \mathrm{kPa}<S_{u}<100 \mathrm{kPa}\right)$, very stiff clay $\left(100 \mathrm{kPa}<S_{u}<\right.$ $150 \mathrm{kPa})$, and hard clay $\left(S_{u}>150 \mathrm{kPa}\right)$. The area between the dashed lines running parallel on both sides of the river represents the "effective correlation distance" between the soil parameter and the factors. The focus is to estimate the soil variability in within this distance from the river because (1) 


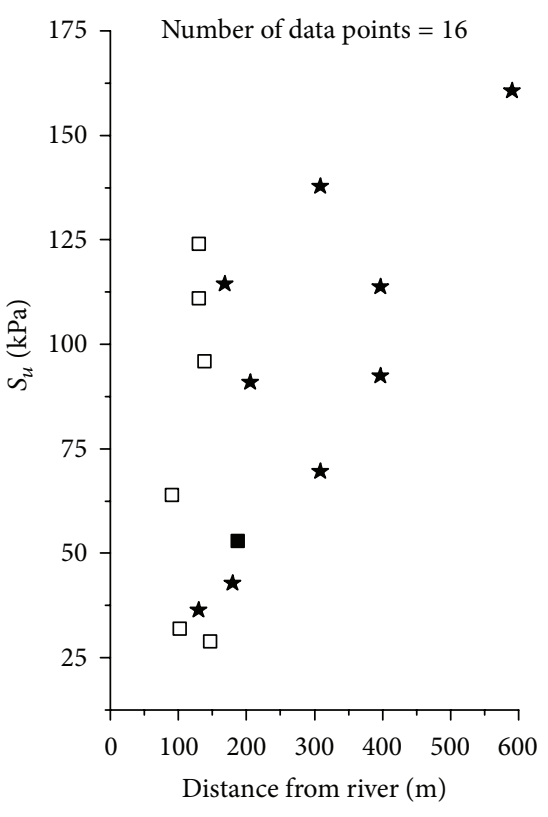

(a)

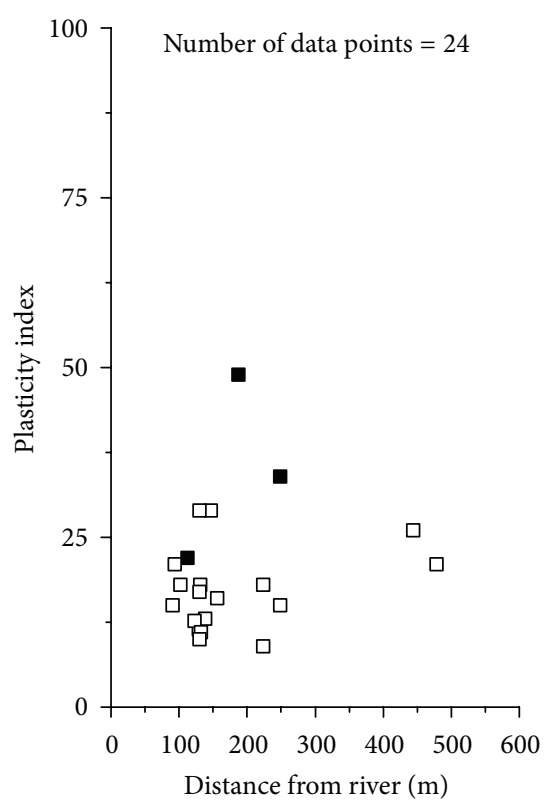

$S_{u}$ from USACE 1987 [36] report triaxial compression lab testing

- $\mathrm{CH}$ : fat clays

$\square$ CL: lean clays

$S_{u}$ derived from URS CPTs using

a correlated value of $\mathrm{Nkt}=20$

$\star$ Clays (as per Olsen and Mitchell classification charts)

(c)

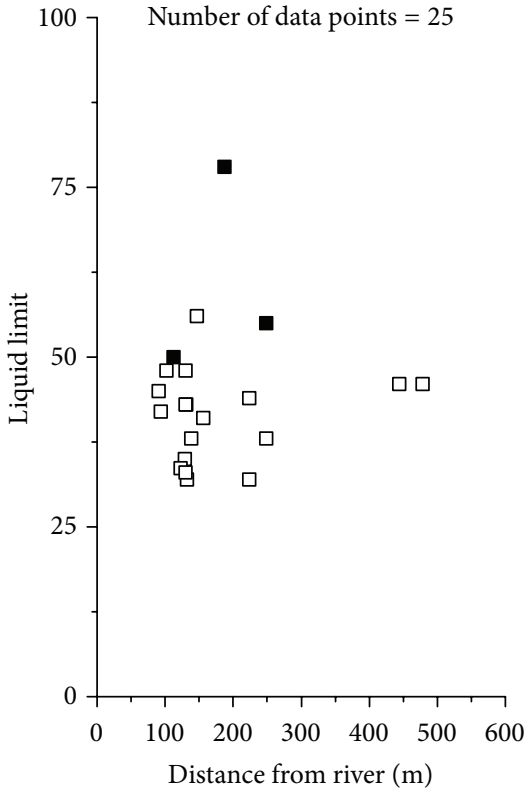

(b)

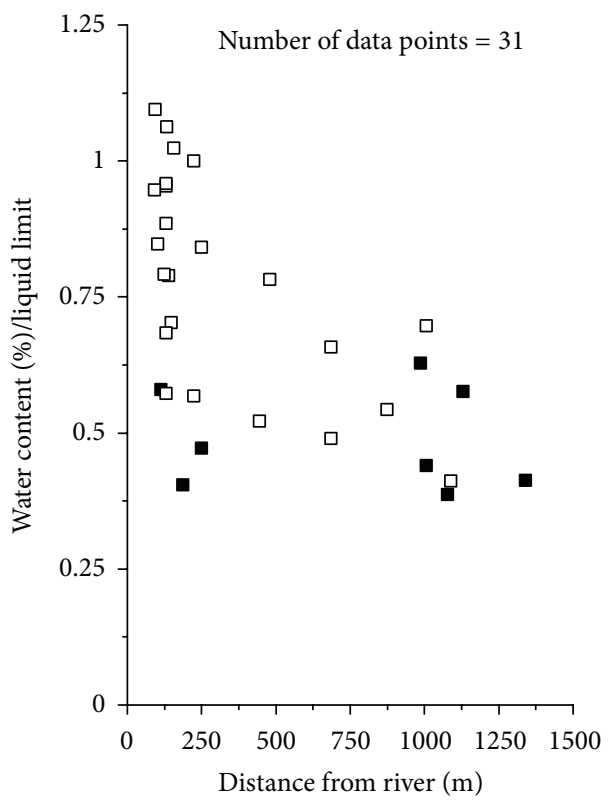

$S_{u}$ from USACE 1987 [36] report triaxial compression lab testing

- $\mathrm{CH}$ : fat clays

$\square$ CL: lean clays

$S_{u}$ derived from URS CPTs using a correlated value of $\mathrm{Nkt}=20$

$\star$ Clays (as per Olsen and Mitchell classification charts)

(d)

FIGURE 11: Relation of shallow clay soil parameters to distance from centerline of closest river segment in Sacramento. 
TABLE 12: "Effective correlation distance" and "sinuosity index segmentation level" for soil layers in Feather River area.

\begin{tabular}{|c|c|c|c|c|c|c|c|c|c|}
\hline \multirow{2}{*}{ Location } & \multirow{2}{*}{ Material } & \multirow{2}{*}{ Depth } & \multirow{2}{*}{ SI segmentation level $(\mathrm{m})$} & \multicolumn{6}{|c|}{ Effective correlation distance $(\mathrm{m})$} \\
\hline & & & & $\phi$ & Fines & $S_{u}$ & LL & PI & WC/LL \\
\hline \multirow{3}{*}{ Feather River } & Clay & Shallow & 1000 & - & - & 600 & 600 & 600 & 600 \\
\hline & Sand & Shallow & 1000 & 450 & 450 & - & - & - & - \\
\hline & Clay & Deep & 1000 & - & - & $600^{\mathrm{a}}$ & $600^{\mathrm{a}}$ & $600^{\mathrm{a}}$ & $600^{\mathrm{a}}$ \\
\hline
\end{tabular}

${ }^{\mathrm{a}}$ Data available only from Feather River South.

TABLE 13: Parameters from the ordinary kriging semivariograms of identified soil layers in the study areas.

\begin{tabular}{|c|c|c|c|c|c|c|c|}
\hline Location & Depth & Material & Parameter & Unit & Correlation range $(\mathrm{m})$ & Nugget $^{\mathrm{a}}$ & Partial sill $^{\mathrm{a}}$ \\
\hline \multirow{4}{*}{ Sacramento City } & Shallow & Clay & $S_{u}$ & $\mathrm{kPa}$ & 819 & 19.5 & 1730 \\
\hline & Shallow & Sand & $\phi$ & Degrees & 400 & 0.3 & 3 \\
\hline & Deep & Clay & $S_{u}$ & $\mathrm{kPa}$ & $-{ }^{\mathrm{b}}$ & & \\
\hline & Deep & Sand & $\phi$ & Degrees & $177^{\mathrm{c}}$ & 1 & 17 \\
\hline \multirow{3}{*}{ Feather River } & Shallow & Clay & $S_{u}$ & $\mathrm{kPa}$ & $-{ }^{\mathrm{b}}$ & & \\
\hline & Shallow & Sand & $\phi$ & Degrees & 407 & 1 & 11 \\
\hline & Deep & Clay & $S_{u}$ & $\mathrm{kPa}$ & $-^{\mathrm{b}}$ & & \\
\hline
\end{tabular}

${ }^{a}$ Units of these elements is the "square of the corresponding parameter unit".

${ }^{\mathrm{b}}$ No kriging estimate could be done due to limited number of data points available for the $S_{u}$ parameter of this layer.

${ }^{\mathrm{c}}$ The low value of the range for the deep Sacramento River as compared to the other sand layers is due to limited number of data points at large distances for this particular layer.

TABLE 14: Simplified damage potential criteria used for underseepage and liquefaction.

\begin{tabular}{lcccc}
\hline Levee material & Clay & Sand & Clay & Sand \\
Foundation material & Clay & Clay & Sand & Of concern \\
\hline Underseepage & Of no concern & Of little concern & Of some concern \\
Liquefaction & Of no concern & Of some concern & Of some concern & Of concern \\
\hline
\end{tabular}

correlation of soil strength parameters with regional factors has been established with this limitation and (2) this distance is far enough from the levee in a way that the soil parameter values beyond that will not affect the response of the levee fill.

\subsection{Adjustment of Kriging Estimate Using Regional Corre-} lations. A uniform grid of points was established within the effective correlation area from the river center. At these grid locations the estimated kriging $S_{u}$ values were read and adjusted as needed to reflect the correlations with regional factors. A large grid size would not capture the correlations with the regional factors, nor will it capture the effect of spatial autocorrelation of individual soil parameters, and a confirmation of the most effective grid size requires field validation of the estimated parameters. Each location on the grid is assigned the attributes of (1) experimental kriging estimate value (Figure 17), (2) distance to closest segment of river, (3) geology layer, and (4) sinuosity of closest segment of river. These attributes are then used to represent the grid points on the plots of shear strength parameter $S_{u}$ versus the corresponding factors.

Curve fits established between the soil strength parameters and the regional factors serve as a check to the ordinary kriging estimation method. Any grid location that exhibits values falling away from these established regional factor trends will have its $S_{\mathcal{u}}$-kriging-estimate value revised in order to fall within an acceptable confidence level, that is, a defined number of standard deviations, from the value at the best fit curve. Standard error/deviation can be defined for any distribution with finite first two moments, but it is most common to assume that the underlying distribution is normal. Once updates are made to all values that need adjustment, the kriging estimation map is recalculated, taking into account those updated values at the relevant grid point locations. The revised kriged map at the end of the modeling process is itself a continuous spatial distribution of the soil parameter estimates, and as such the value of the adjusted estimated parameter is read from any location within the effective correlation area on the map.

\section{Response of Levee Segments}

As previously mentioned, two critical failure modes of levee failure were considered in this study: failure due to excessive underseepage and failure due to liquefaction of the levee material or the foundation soils. Spatial joins were used to combine the levee and foundation material attributes (Figure 4). For simplicity at this stage of research, levee material was classified as a single layer (sand or clay) based on the major overall impression from soil investigation borehole data through the levee. The underlying geology map was used as the foundation layer and similarly classified in a rudimentary manner (sand or clay). 


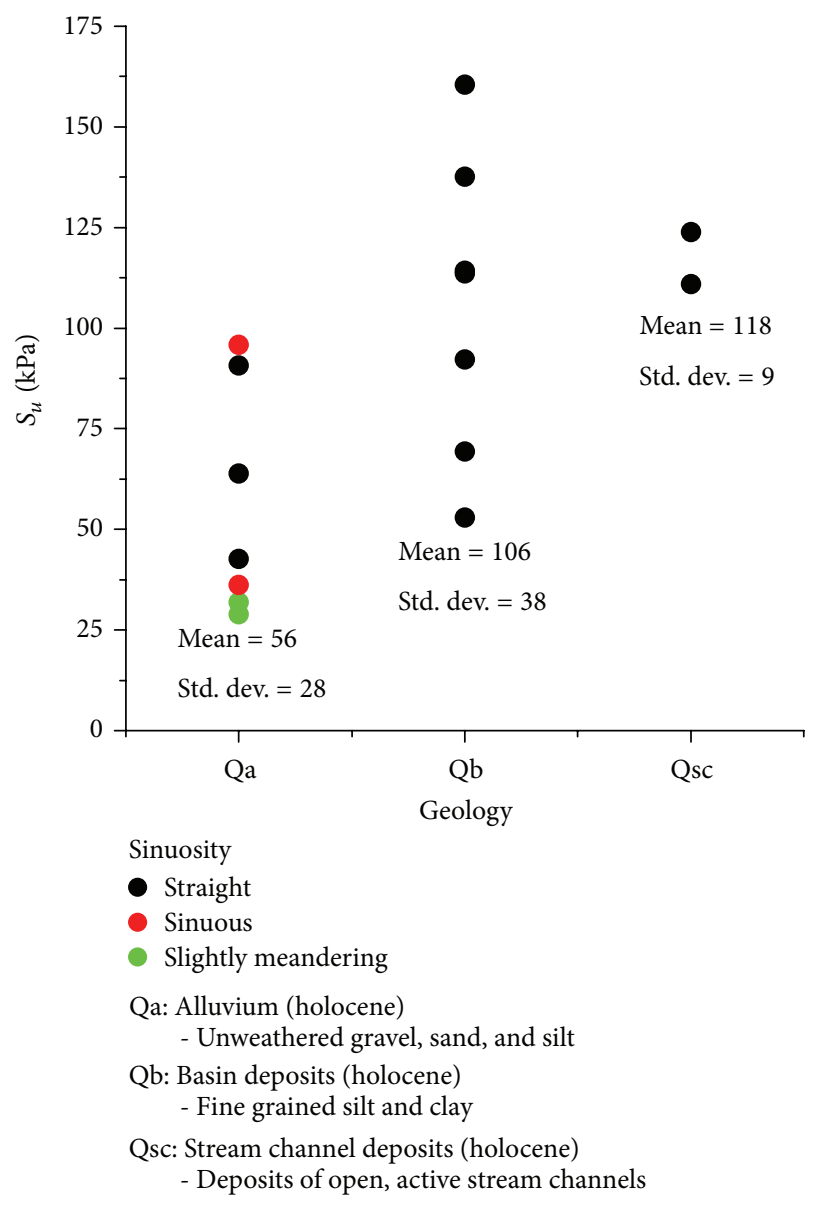

FIGURE 12: Relation of $S_{u}(\mathrm{kPa})$ shallow clay soil parameter in Sacramento to geology, categorized as per sinuosity index.

Underseepage is one of the most common causes of levee failure that can occur either in the levee material or the underlying foundation. Sands, loose and dense, have a higher permeability than clays and thus are more prone to this particular mode of failure. Furthermore, deeper sand layer constituting the foundation under the levee will have a higher hydraulic gradient and thus will be more critical for underseepage than the case of sand in the levee itself. For seismic events, analysis for levee loss of freeboard due to soil liquefaction relies on preestablished typical levee crosssection analysis [13] by (1) characterizing the levee at each location as one of many typical levee cross-section profiles, (2) inputting the specific geometric characteristics and soil parameter values specific to the levee and foundation layers at that location, and (3) evaluating the distribution of the cyclic stress ratio (CSR), a measure for probability of triggering of liquefaction, for the levee cross sections.

A simplistic failure probability estimation criterion was used for this first-order analysis. Each soil layer combination, in this case the levee material and the foundation soil, is given a qualitative measure of failure potential due to either excessive underseepage or liquefaction. Results from the analyses are shown in Figure 19, and the criteria used in the initial analysis maps are summarized in Table 14.

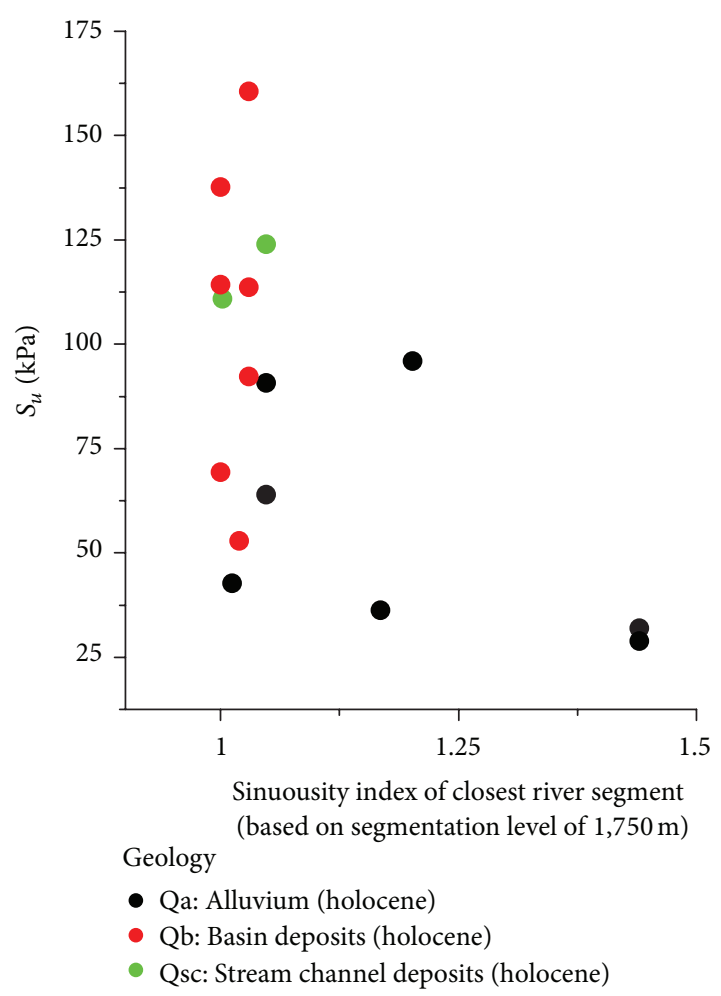

FIgURE 13: Relation of $S_{u}(\mathrm{kPa})$ shallow clay soil parameter in Sacramento to sinuosity index, categorized as per regional geology.

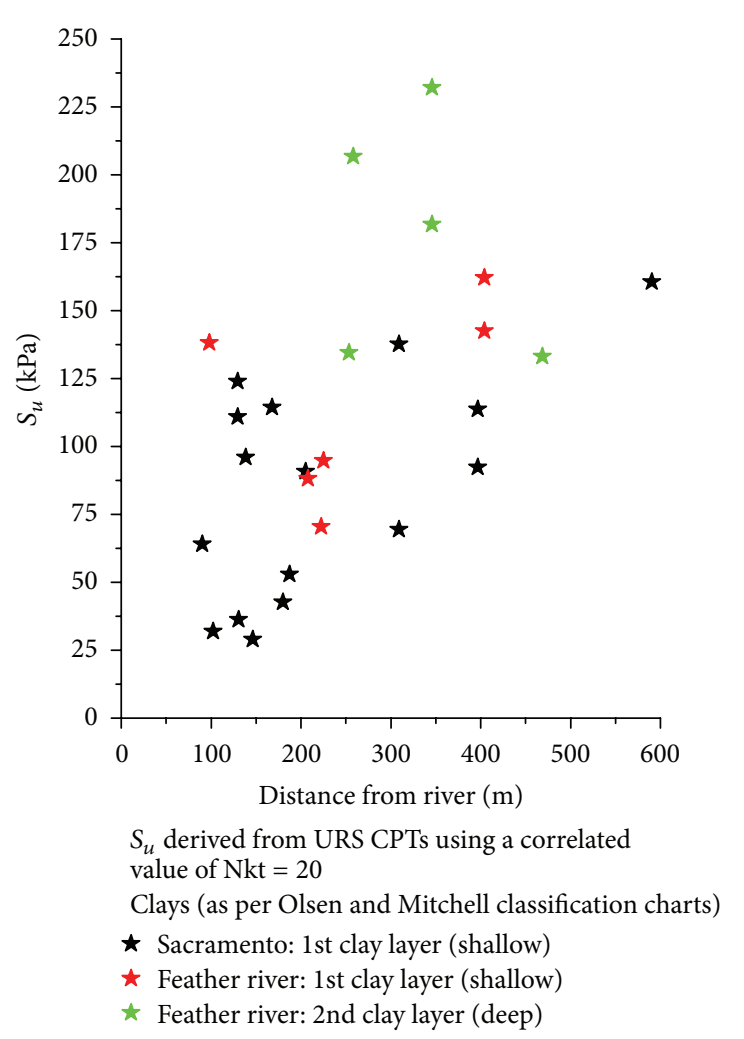

FIgURE 14: Relation of $S_{u}(\mathrm{kPa})$ soil parameter to distance from centerline of closest river segment, in Sacramento and Feather River for both shallow and deep layers of clay. 


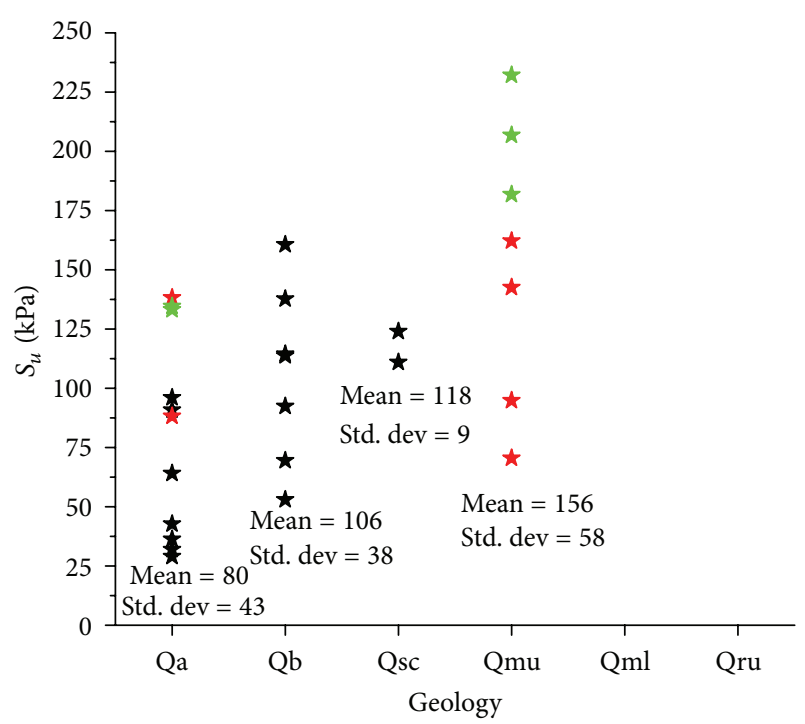

$S_{u}$ derived from URS CPTs using a correlated value of $\mathrm{Nkt}=20$

Clays (as per Olsen and Mitchell classification charts)

$\star$ Sacramento: 1 st clay layer (shallow)

$\star$ Feather river: 1 st clay layer (shallow)

$\star$ Feather river: 2 nd clay layer (deep)

Qa: Alluvium (holocene)

Qb: Basin deposits (holocene)

Qsc: Stream channel deposits (holocene)

Qmu: Upper member-modesto

formation (pleistocene)

Figure 15: Relation of $S_{u}(\mathrm{kPa})$ soil parameter to geology, in Sacramento and Feather River for both shallow and deep layers of clay.

\section{Flood Scenarios, Damage Forecasting, and System Risk Assessment}

The next step consisted of modelling the possible flood scenarios for all levee segments and then using a colour code for flooding of segments of either no, little, or more concern for failing due to both excessive underseepage and liquefaction. This was done using terrain slope and flow patterns obtained by analyzing a $10 \mathrm{~m} \times 10 \mathrm{~m}$ digital elevation model data. This was mainly achieved using the ArcGIS watershed tool, among others, in the model builder environment. This tool calculates all the area contributing flow to a particular point at a lower level. Since levees are at a higher level than the adjacent land and the objective is to get the area where water would flood (as opposed to water collecting downstream an area to a point), a digital elevation model was inverted, and the watershed tool was applied to it with water flowing towards the levee locations where failure would occur. The resulting flood scenarios for all levee segments, using the two considered methods of failure, were consistent with the landscape and terrain properties and are shown in Figure 20. Note that the presented flood model does not simulate the effect of water accumulation in the flooded areas, nor does it indicate where the water would ultimately go after a steady flow for a period of time. The model assumes that all the levee

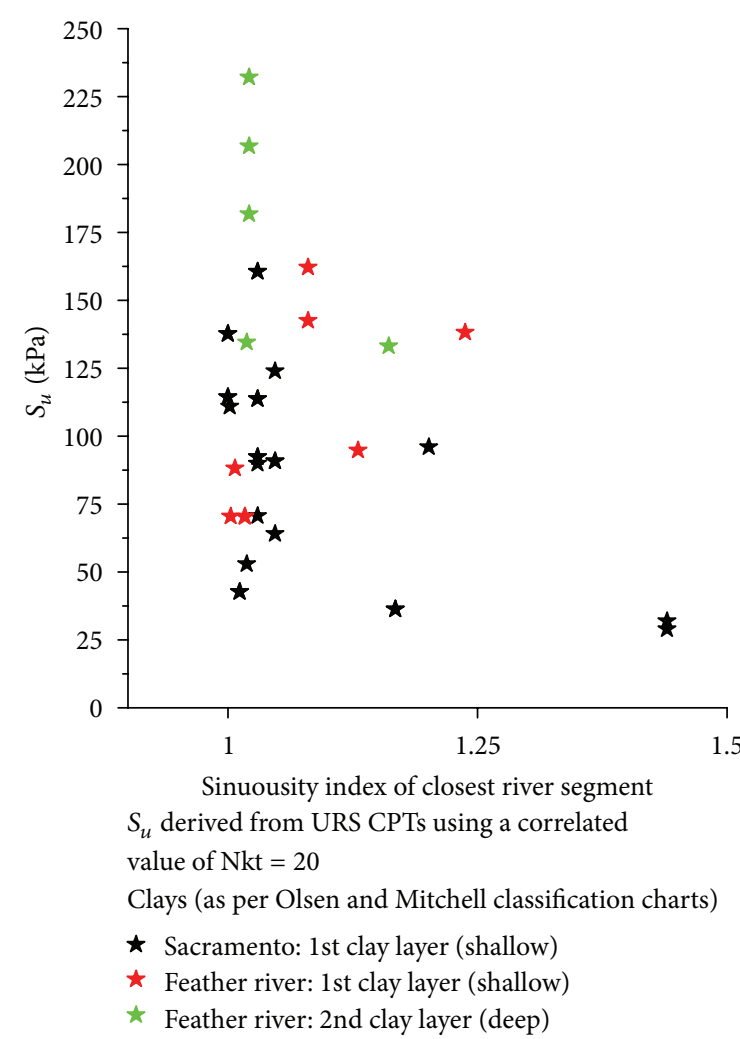

FIGURE 16: Relation of $S_{u}(\mathrm{kPa})$ soil parameter to sinuosity index, in Sacramento and Feather River for both shallow and deep layers of clay.

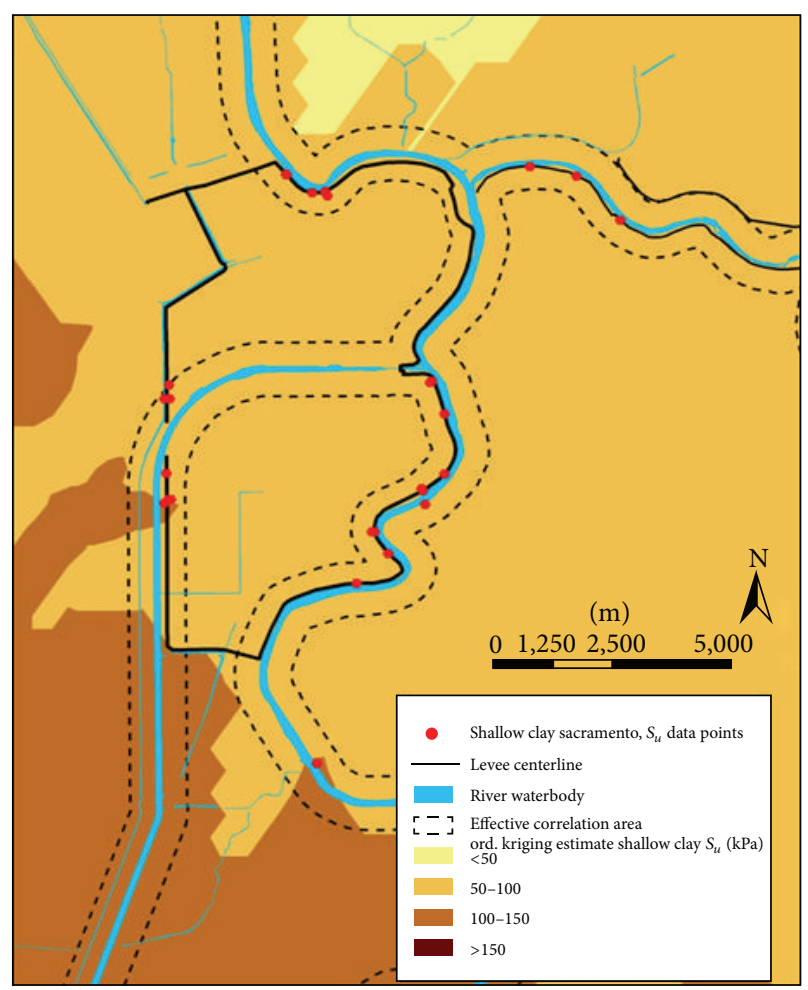

FIGURE 17: Sample output map of the ordinary kriging method applied for the $S_{u}$ values in shallow clay layer of Sacramento. 


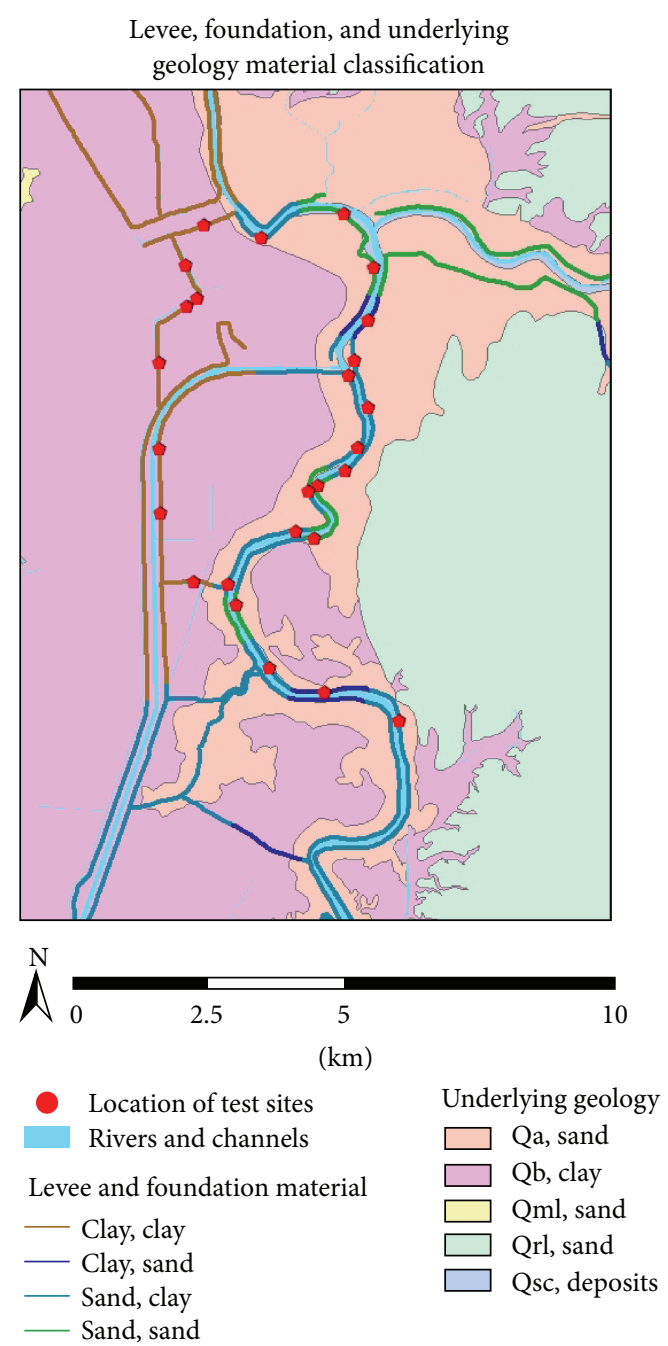

FIGURE 18: Levee and foundation material classification with underlying geology of the study area.

section that has failed is completely nonexistent physically, which is a worst case scenario; thus these calculations are conservative.

Flooded areas, as determined in the previous step, were combined and overlapped in the GIS platform with population data and presented in a 3D format using the ArcScene software. This step is performed to show the ease of visual representation and usefulness of the proposed work in helping decision makers and engineers to plan maintenance, repair, and emergency response operations. Finally, individual segment and overall levee system risk measures are assessed as a function of response analysis and resulting damage estimation by developing fragility curves for a range of ground motion intensities.

\section{Conclusions}

The proposed approach, even though simplified, offers a firstorder estimate of the spatial vulnerability of a levee system and an efficient visualization of the results, thus enabling decision makers to quickly identify critical regions. This is achieved by combining a geostatistical model of spatial soil variability with simplified approaches for estimating underseepage and soil liquefaction levee vulnerability. Finally, GIS is used as the platform for manipulating and presenting information. A number of simplifications and assumptions have been made in order to complete the above analysis. This mainly involves the estimation of soil properties along the levee segments between the points with "known" properties and to a lesser extent the determination of the exact flooded areas (Figures 18 and 19). The soil properties' variability issue needs to be addressed using a more detailed geostatistical spatial analysis approach in the future.

As a result of analyzing geotechnical investigation data in the area of study, the concept of "effective correlation distance" between the soil parameters and regional factors is introduced. This is a physical representation of the distance beyond which no trend/correlation was observed or deemed physically significant. For clay parameters this distance came out to be $600 \mathrm{~m}$ from either side of the river centerline. For sand parameters the distance was $450 \mathrm{~m}$. Possible explanation of why sand distance is less than clay distance may be in the fact that sands settle closer to the levee in times of overtopping flooding due to larger heavier particle size as compared to silts and clays. Note that in Sacramento, the average river width is $150 \mathrm{~m}$, and levees are typically around $100 \mathrm{~m}$ from the river centerline (i.e., on average 25 meters from river edge). Thus, for example, the limit of this effective correlation distance for clays is still $500 \mathrm{~m}$ away from the levees, which can be approximated as free-field conditions.

Another concept established is the "sinuosity index segmentation level." This is a reflection of the river meander length period. Based on the available data, the ideal segmentation level was found to be close to 10 times the river channel width. Values imply that the Feather River (1,000 m segmentation) has a shorter meander length than the Sacramento River (1,750 m segmentation) that is, the Feather River meanders in shorter meander wave lengths than the Sacramento River.

The main finding of the soil variability model is the establishment of a number of correlations between soil strength parameters (friction angle, $\phi$, for sands and shear strength, $S_{u}$, for clays) and a number of regional characteristics (underlying geology type, distance to river, and sinuosity of river). The correlations were studied for naturally occurring clay and sand typical foundation layers, located at both shallow and deep levels, in both regions of Sacramento and Feather Rivers.

The major findings from the development of the soil parameters estimation model, based on the above mentioned established correlations, are the following.

(i) Clay in both shallow and deep layers and in both areas of study (Sacramento and Feather River) showed increasing trend of $S_{u}$ with increasing distance from river (Figure 14). $S_{u}$ values also increased with depth, which may be attributed to consolidation of the deeper layers over time.

(ii) As for relation of $S_{u}$ to the different geological formations in the two study areas (Figure 15), a general observation is that clay $S_{u}$ values in the areas of the 


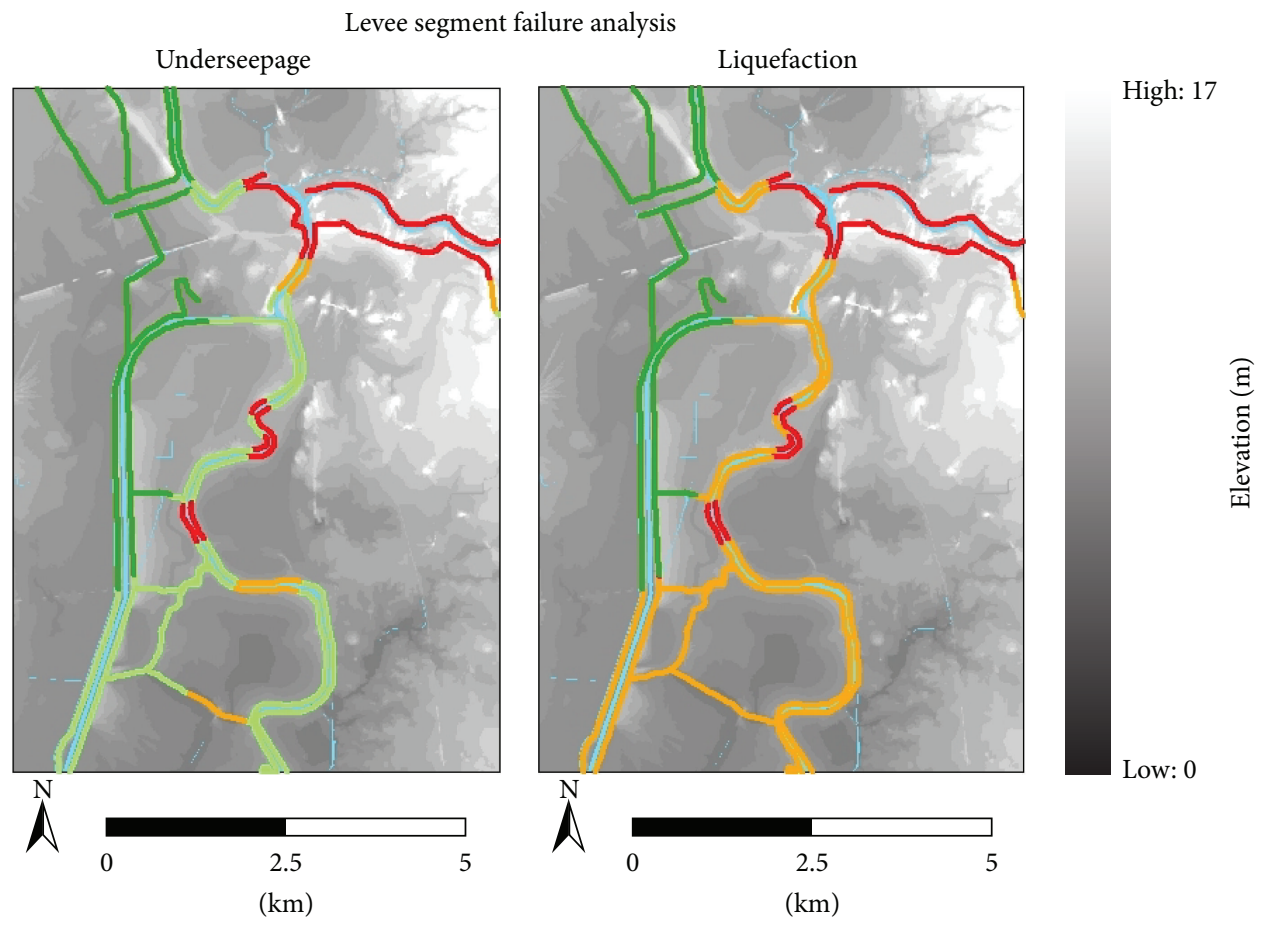

Rivers and channels

Failure criteria

$\begin{array}{ll}\text { Of no concern } & \text { Of some concern } \\ \text { Of little concern } & \text { Of concern }\end{array}$

FIGURE 19: Results for failure analysis due to underseepage and liquefaction.
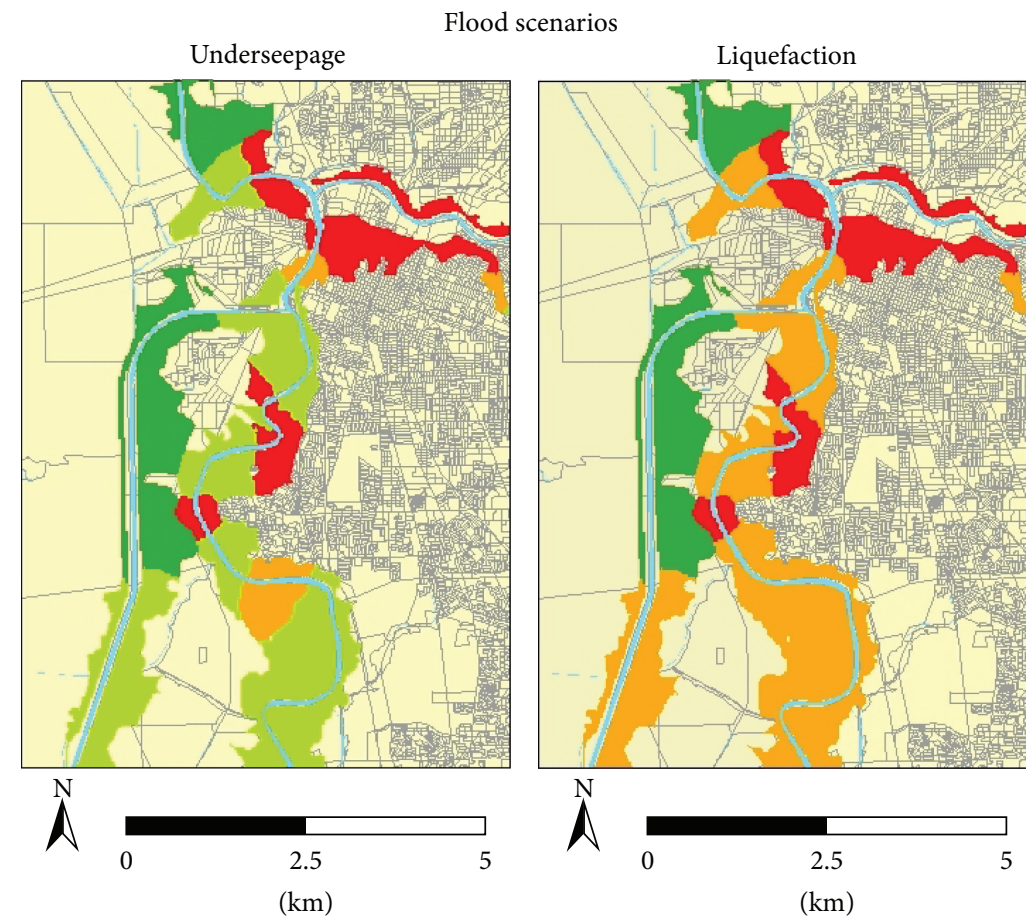

Census blocks

Rivers and channels

Flood risk

$\square$ Of no concern $\square$ Of some concern
$\square$ Of little concern $\square$ Of concern

FIGURE 20: Flood scenarios from underseepage and liquefaction failures for all levee segments. 
Qa formation (defined as Alluvium-unweathered gravel, sand, and silt) tend to have lower values than other areas. The fact that clay is not the main component in this formation might provide an explanation for the lower values of $S_{u}$ for any clay showing in these areas, as compared to other formations.

(iii) For $S_{u}$ relation to sinuosity index (Figure 16) there is a large scatter, at lower sinuosity levels. The higher number of data points at this low sinuosity level is due to the smaller number of river segments that are highly sinuous. An important observation across all areas of study and at all depths of layers is that $S_{u}$ tends to decrease with increasing sinuosity of the closest river segment. However, more data points are needed to develop more robust correlations between SI and shear strength or soil type. Furthermore, due to the specific case study area that was used, the limited data used was primarily available for SI values close to 1 (i.e., straight river sections).

Global observations that apply across the larger area of study included the increasing trend of shear strength, $S_{\mathcal{u}}$, with increasing distance from the river and decreasing trend of $S_{u}$ with increasing river sinuosity index levels. This study also presents a framework that can be used for future studies in the development of spatial correlations of soil properties.

\section{Acknowledgments}

The authors would like to thank Matt Hartigan, undergraduate student at the University of Michigan, who helped with the processing of some of the shear strength data as part of the Undergraduate Research Opportunities Program (UROP) at the University of Michigan. The authors are also grateful to the Rackham School of Graduate Studies for awarding Mustafa Saadi the Rackham Graduate Student Research Grant during his last year at the University of Michigan.

\section{References}

[1] ASCE, "Report Card for America’s Infrastructure," 2013, http:// www.infrastructurereportcard.org/.

[2] DWR, "California department of water resources," 2011, http:// www.water.ca.gov/.

[3] URS, "Technical memorandum-levee seismic vulnerability assessment methodology," in Urban Levee Geotechnical Evaluations Program, 2008.

[4] K.-K. Phoon and F. H. Kulhawy, "On quantifying inherent soil variability, uncertainty in the geologic environment," in Proceedings of the Analysis and Computation Specialty Conference, Madison, Wis, USA, 1996.

[5] N. D. Gordon, T. A. McMahon, B. L. Finlayson, C. J. Gippel, and R. J. Nathan, Stream Hydrology, John Wiley \& Sons, New York, NY, USA, 2nd edition, 2004.

[6] J. E. Mueller, "An introduction to the hydraulic and topographic sinuosity indexes 1," Annals of the Association of American Geographers, vol. 58, no. 2, pp. 371-385, 1968.

[7] Z. Deretsky, Ten Ways a Levee Can Fail, National Science Foundation, 2010.
[8] ASCE, So You Live Behind a Levee? American Society of Civil Engineers, 2010.

[9] USGS, "United States national seismic hazard maps," 2008, http://earthquake.usgs.gov/hazards/products/conterminous/ $2008 /$.

[10] RESIN, "Resilient and sustainable infrastructure networks project (RESIN) at the University of California Berkeley," 2011, http://ccrm.berkeley.edu/resin/index.shtml.

[11] DRMS, Initial Technical Framework Paper: Levee Fragility, Delta Risk Management Strategy, 2006.

[12] DRMS, Initial Technical Framework Paper: Sacramento-San Joaquin Delta Risk Analysis (Approach and Basis of Analysis), Delta Risk Management Strategy, 2006.

[13] A. M. Athanasopoulos-Zekkos, Select topics on the static and dynamic response and performance of earthen levees [Ph.D. thesis], Department of Civil and Environmental Engineering, University of California Berkeley, Berkeley, Calif, USA, 2008.

[14] A. Athanasopoulos-Zekkos and R. B. Seed, "Simplified methodology for consideration of 2D dynamic response of levees in liquefaction triggering evaluation," ASCE Journal of Geotechnical and Geoenvironmental Engineering, vol. 139, no. 11, pp. 19111922, 2013.

[15] USACE, "Guidelines for the seismic evaluation of Levees," ETL 1110-2-580, Department of the Army, Washington, DC, USA, 2013.

[16] FEMA, "FEMA-366: HAZUS-MH estimated annualized earthquake loss for the United States," 2009, http://www.fema.gov/ library/viewRecord.do?id=3265.

[17] USACE, Levee Investigation, Reclamation District's 537 and 900 and Maintenance Areas 4 and 9, Sacramento River, Sacramento Bypass and Yolo Bypass, Yolo and Sacramento Counties, California, Department of the Army, Office of the Chief of Engineers, U.S. Army Corps of Engineers, 1987.

[18] F. H. Kulhawy and P. W. Mayne, "Manual on estimating soil properties for foundation design," Tech. Rep. EL-6800, Electric Power Research Institute, Palo Alto, Calif, USA, 1990.

[19] R. B. Peck, W. E. Hanson, and T. H. Thornburn, Foundation Engineering, Wiley \& Sons, New York, NY, USA, 2nd edition, 1974.

[20] J. H. Schmertmann, "Measurement of in-situ shear strength," in Proceedings of the Conference on In Situ Measurement of Soil Properties, vol. 2, pp. 57-138, American Society of Civil Engineers, Raleigh, NC, USA, 1975.

[21] M. Hatanaka and A. Uchida, "Empirical correlation between penetration resistance and internal friction angle of sandy soils," Soils and Foundations, Japanese Geotechnical Society, vol. 36, no. 4, pp. 1-9, 1996.

[22] G. B. Baecher and J. T. Christian, "Spatial variability and geotechnical engineering," in Reliability Based Design in Geotechnical Engineering: Computations and Applications, K.-K. Phoon, Ed., Taylor \& Francis, 2008.

[23] S. Lacasse and F. Nadim, "Uncertainties in characteristic soil properties," in Proceedings of the ASCE Specialty Conference on Uncertainty in the Geologic Environment: From Theory to Practice, 2006.

[24] I. K. Lee, W. White, and O. G. Ingles, Geotechnical Engineering, Pitman, London, UK, 1983.

[25] P. Lumb, “The variability of natural soils," Canadian Geotechnical Journal, vol. 3, no. 2, pp. 74-97, 1966.

[26] P. Lumb, "Application of statistics in soil mechanics," in Soil Mechanics: New Horizons, I. K. Lee, Ed., chapter 3, American Elsevier, 2nd edition, 1974. 
[27] J. Christian and G. Baecher, "Unresolved problems in geotechnical risk and reliability," in Proceedings of the ASCE Geotechnical Risk Assessment and Management Conference (GeoRisk '11), pp. 50-63, American Society of Civil Engineers, Atlanta, Ga, USA, 2011.

[28] G. A. Fenton and D. V. Griffiths, Risk Assessment in Geotechnical Engineering, John Wiley \& Sons, New York, NY, USA, 2008.

[29] J. R. Hess, G. L. Sills, R. Costa, and S. Shewbridge, "California's levees at risk," Geo-Strata-Geo Institute of ASCE, vol. 7, no. 6, pp. 24-28, 2006.

[30] USGS, "National mapviewer," 2010, http://viewer.nationalmap .gov/viewer/.

[31] E. J. Helley and D. S. Harwood, Geologic Map of the Late Cenozoic Deposits of the Sacramento Valley and Northern Sierran Foothills California, Miscellaneous Field Studies Map MF-1790, U.S. Geological Survey, 1985.

[32] J. F. Mount, California Rivers and Streams: The Conflict Between Fluvial Process and Land Use, University of California Press, Berkeley, Calif, USA, 1995.

[33] P. Julien, River Mechanics, Cambridge University Press, Cambridge, UK, 1st edition, 2002.

[34] C. R. Thorne, R. D. Hey, and M. D. Newson, Applied Fluvial Geomorphology for River Engineering and Management, John Wiley \& Sons, New York, NY, USA, 1997.

[35] L. B. Leopold, M. G. Wolman, and J. P. Miller, Fluvial Processes in Geomorphology, W. H. Freeman, Hampshire, UK, 1964.

[36] USGS, "National water information system: web interface," 2011, http://nwis.waterdata.usgs.gov/nwis.

[37] URS, "Geotechnical investigation data for West Sacramento, American River, Marysville, Sutter, and RD784," Personal Communication with Mr. Richard Millet, Vice President, Program Manager DWR Geo-Levee, URS Corporation, 2010.

[38] T. Lunne, P. K. Robertson, and J. J. M. Powell, Cone Penetration Testing in Geotechnical Practice, Blackie Academic \& Professional, New York, NY, USA, 1997.

[39] P. K. Robertson and R. G. Campanella, "Interpretation of cone penetration tests. Part I: sand," Canadian Geotechnical Journal, vol. 20, no. 4, pp. 718-733, 1983.

[40] R. S. Olsen and J. K. Mitchell, "CPT stress normalization and prediction of soil classification," in Proceedings of the International Symposium on Cone Penetration Testing (CPT '95), Linkoping, Sweden, 1995.

[41] ASTM, 2011. ASTM Standard D2487-11, "Standard practice for classification of soils for engineering purposes (unified soil classification system)," Tech. Rep., ASTM International, West Conshohocken, Pa, USA, 2003, http://www.astm.org/. 


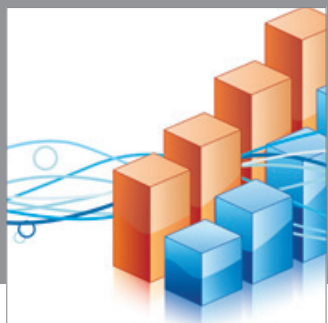

Advances in

Operations Research

mansans

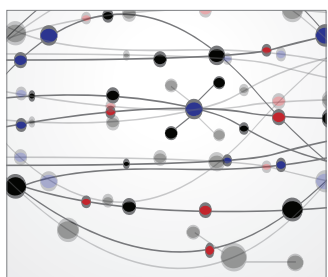

The Scientific World Journal
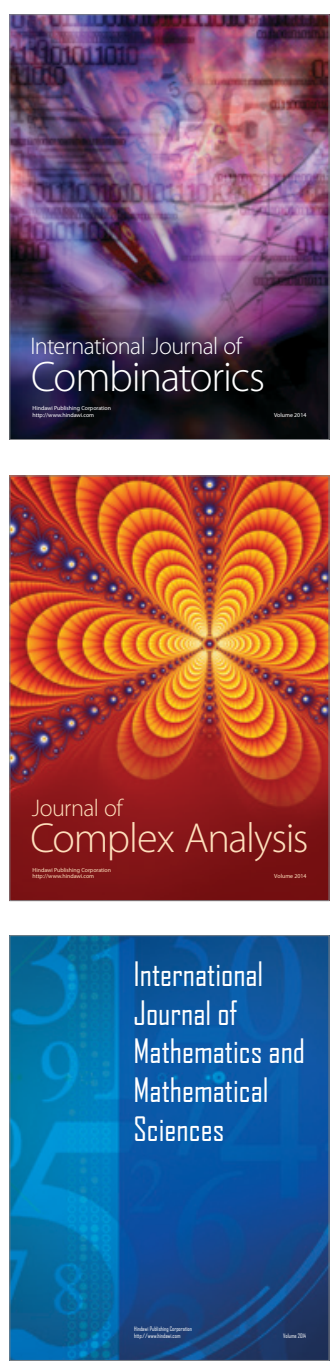
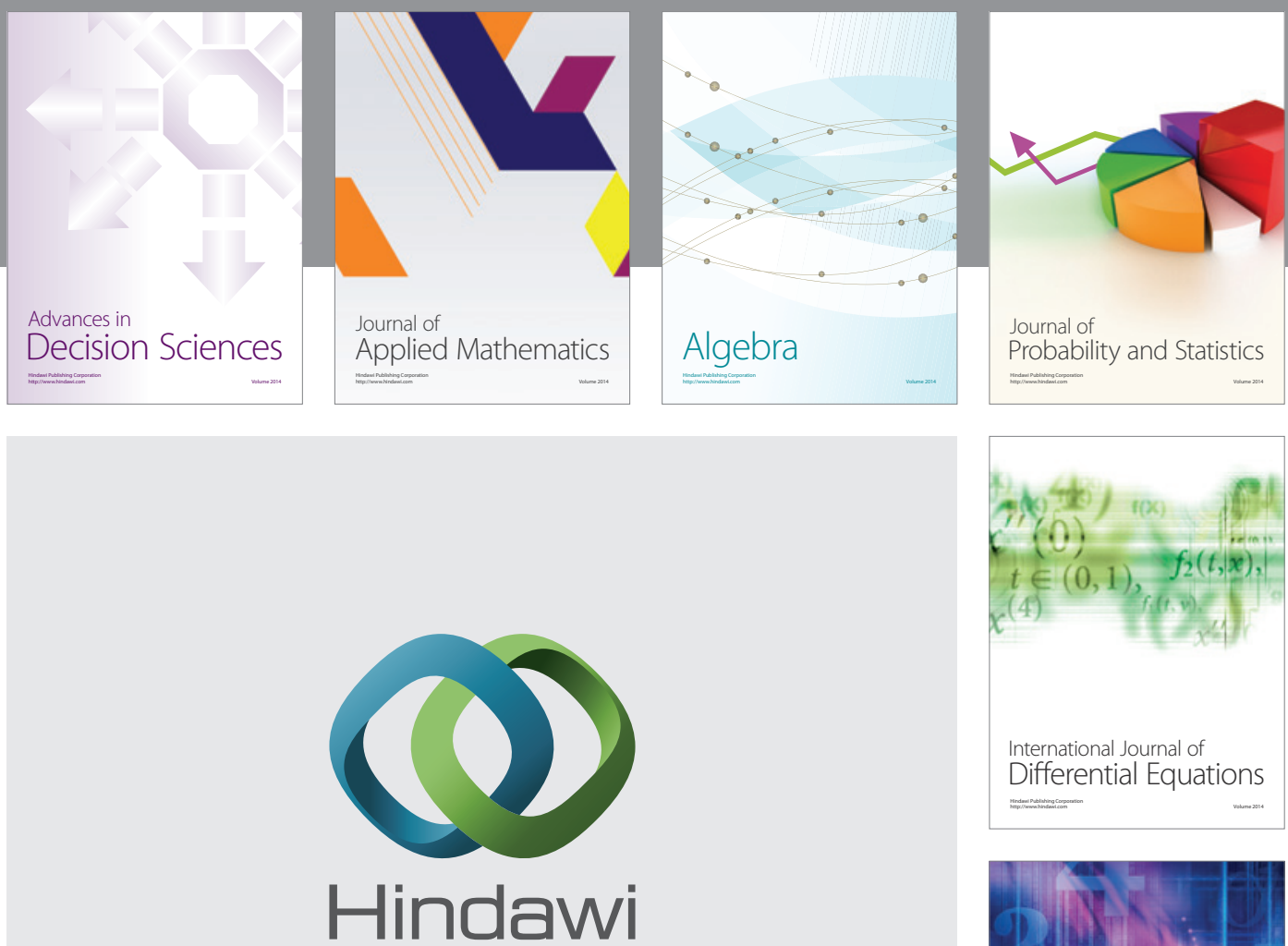

Submit your manuscripts at http://www.hindawi.com
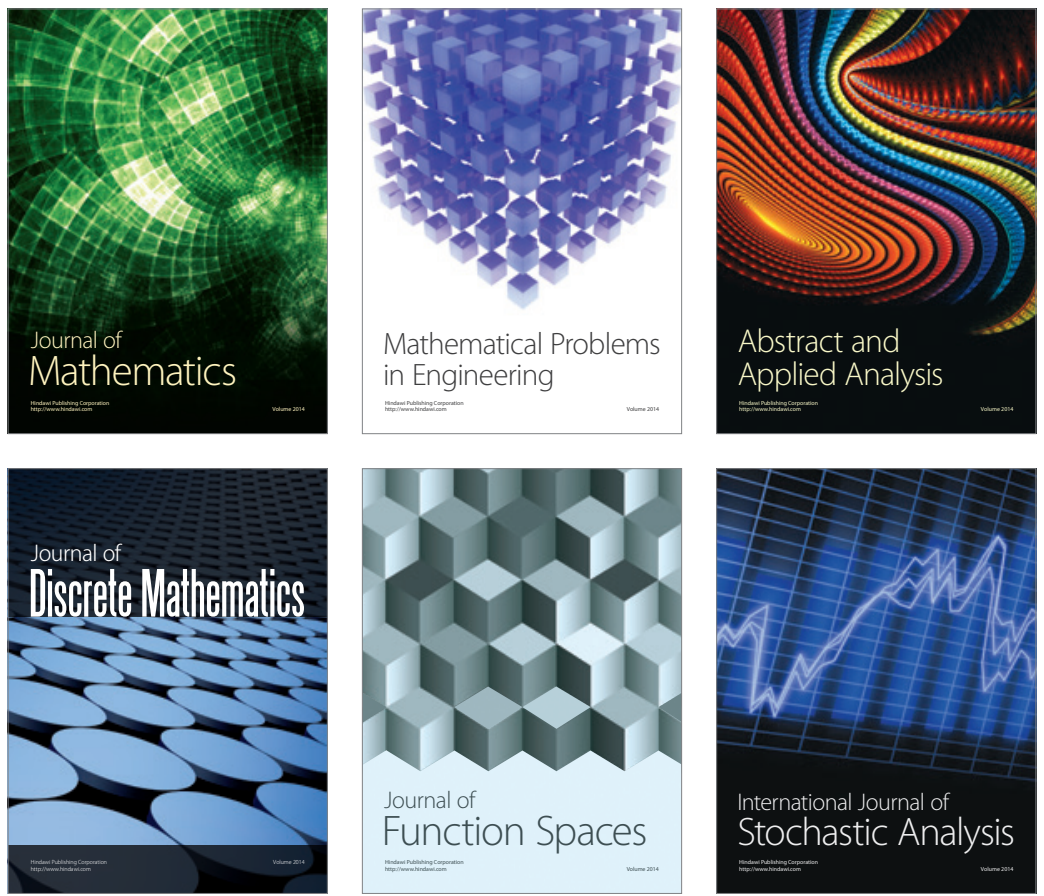

Journal of

Function Spaces

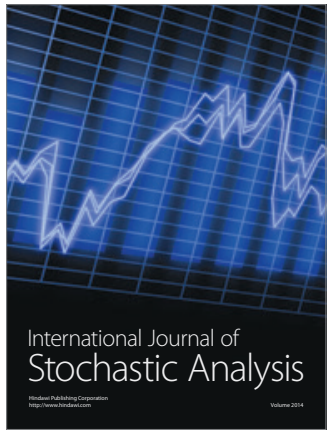

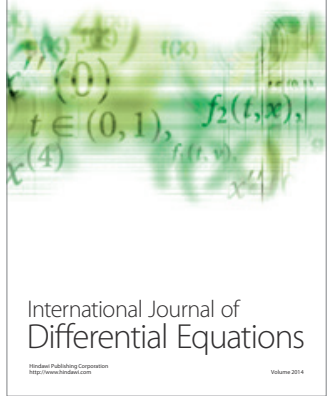
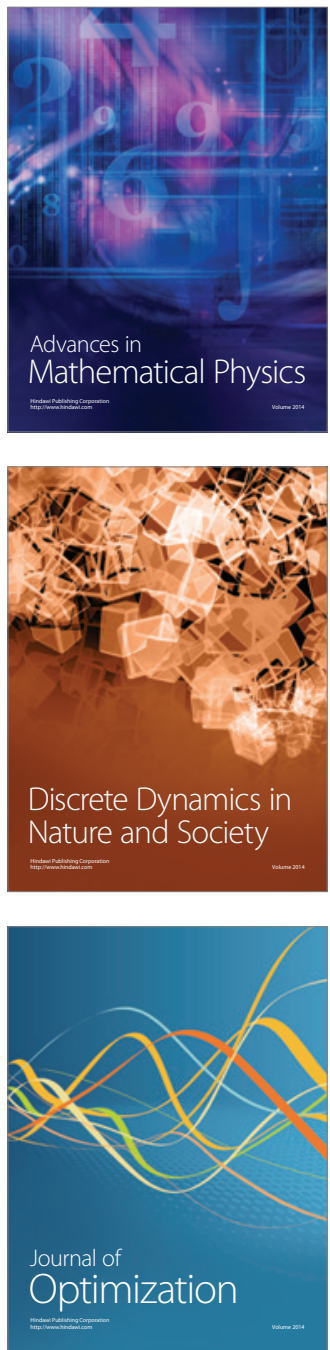